\title{
Review
}

\section{Fabricating Sustainable All-Cellulose Composites}

\author{
Eija-Katriina Uusi-Tarkka ${ }^{1, *}$, Mikael Skrifvars ${ }^{2}\left(\right.$ and Antti Haapala ${ }^{1}(0)$ \\ 1 Faculty of Science and Forestry, School of Forest Sciences, University of Eastern Finland, \\ FI-80101 Joensuu, Finland; antti.haapala@uef.fi \\ 2 Swedish Centre for Resource Recovery, Faculty of Textiles, Engineering and Business, University of Borås, \\ S-50190 Borås, Sweden; mikael.skrifvars@hb.se \\ * Correspondence: eija.uusi-tarkka@uef.fi
}

Citation: Uusi-Tarkka, E.-K.;

Skrifvars, M.; Haapala, A. Fabricating Sustainable All-Cellulose Composites. Appl. Sci. 2021, 11, 10069. https:// doi.org/10.3390/app112110069

Academic Editor: Alejandro

Rodriguez Pascual

Received: 31 August 2021

Accepted: 22 October 2021

Published: 27 October 2021

Publisher's Note: MDPI stays neutral with regard to jurisdictional claims in published maps and institutional affiliations.

Copyright: () 2021 by the authors. Licensee MDPI, Basel, Switzerland. This article is an open access article distributed under the terms and conditions of the Creative Commons Attribution (CC BY) license (https:// creativecommons.org/licenses/by/ $4.0 /)$.

\begin{abstract}
Climate change, waste disposal challenges, and emissions generated by the manufacture of non-renewable materials are driving forces behind the production of more sustainable composite materials. All-cellulose composites (ACCs) originate from renewable biomass, such as trees and other plants, and are considered fully biodegradable. Dissolving cellulose is a common part of manufacturing ACCs, and currently there is a lot of research focused on effective, but also more environmentally friendly cellulose solvents. There are several beneficial properties of ACC materials that make them competitive: light weight, recyclability, low toxicity, good optical, mechanical, and gas barrier properties, and abundance of renewable plant-based raw material. The most prominent ACC applications are currently found in the food packing, medical, technical and vehicle industries. All-cellulose nanocomposites (ACNCs) expand the current research field and can offer a variety of more specific and functional applications. This review provides an overview of the manufacture of sustainable ACCs from lignocellulose, purified cellulose, and cellulosic textiles. There is an introduction of the cellulose dissolution practices of creating ACCs that are currently researched, the structure of cellulose during complete or partial dissolution is discussed, and a brief overview of factors which influence composite properties is presented.
\end{abstract}

Keywords: all-cellulose composite; biocomposite; cellulose; dissolution; natural fibres; singlepolymer composite

\section{Introduction}

Worldwide, an ever-increasing amount of consumable materials is produced and used. At the same time, we are facing severe environmental crises: poor waste management, microplastics in all waterways, depleting natural resources, and increasing greenhouse gases in the atmosphere [1]. It is important that technological development respond to the growing demand for sustainable materials that do not intensify the current waste problem.

Wood- or plant-based cellulose fibres have shown their potential as a reinforcement in composites for a relatively long time [2] alongside the commonly used glass-fibre [3] and carbon-fibre [4] reinforcements. The challenge is finding a bio-based option for the composite matrix, which is responsible for binding the fibres, transferring load, and shaping and protecting the final composite. Using wood-plastics is a step in a more sustainable direction, but they have proven been challenging to recycle [5], and therefore, they also contribute negatively to the waste problem when the material is disposed of. Furthermore, two chemically different components often have poor interfacial compatibility, which can lead to water uptake, reduction of the material's mechanical properties [6] and shortening of the lifespan of the product. One way to overcome this problem and increase recyclability is to create single-polymer composites (SPCs), where reinforcement and matrix are composed of the same materials [7]. This effectively removes the fibre-matrix adhesion challenges between different types of polymers [8]. 
All-cellulose composites (ACCs) can provide an environmentally friendly alternative to conventional petrochemical-based materials since they are a type of SPCs from biomassderived cellulose, and as such, they are easily recyclable, and they originate from renewable sources. A pioneering study of ACC materials was published by Nishino et al. [8], who created a cellulose-based composite with good mechanical and thermal properties. Since then, there has been a growing interest in the research and development of ACC and in finding suitable solvent systems for the process [9-15]. Currently, ACCs are produced from various cellulosic raw materials (plant fibres, chemically pulped wood, textile fibres and different varieties of micro- and nano-celluloses) using different processing methods $[16,17]$. All-cellulose nanocomposites (ACNC) are a subclass of nanocomposites produced using plant- and bacterial-based nanocellulose. They are manufactured via same methods as macroscale ACCs and they can improve the desired properties of the composite material such as enhance its mechanical strength [18-22]. Despite these recent developments, most of the recently developed ACC and ACNC materials are still produced in a laboratory scale.

Cellulose-based biocomposites have already found commercial success in many industries and therefore there are also potential interests for ACC materials. Current legislation and policies also lead the way to more sustainable product manufacturing. For instance, the European Commission's Green Deal action plan [23-25] pushes the transportation industries to more sustainable practices and to generate less carbon dioxide emissions. One solution for the road transport, marine and aviation industries is to replace indoor plastic components with cellulose-based components [26]. Emission reduction occurs not only via the use of sustainable materials but through weight reduction that leads to more efficient fuel consumption [27]. In addition, low-density bio-based composites can improve key performance factors, such as impact resistance, energy absorption capacity, and reduce noise and vibration. They can also offer advantages in production cost [28]. Furthermore, low density ACC materials with good optical and gas barrier properties, flexibility, and high mechanical strength can be used applications in areas such as display panels, photoelectric devices, filtration materials, biomedical engineering applications, high-performance food packaging and structural materials [29,30]. Lightweight, rigid and porous all-cellulose aerogels can be an environmentally friendly alternative to synthetic foams [10] and can be used in technical applications, such as adsorbents, catalysts, detectors and acoustic and thermal insulators, as well as in many life science applications, such as pharmacology, cosmetics and bio-medical applications [31].

This review introduces some of the most essential green solvent-based fabrication routes for making all-cellulose composite materials for versatile end use profiles. In the brief outline on cellulose chemistry and composition we provide an overview on cellulose dissolution and regeneration practices that utilize different solvent systems. Different fabrication routes to combine natural fibres to dissolved matrix systems finally lead to fabrication techniques to obtain single polymer composites from cellulose and how to influence their properties.

\section{Cellulose}

\subsection{Characteristics of Cellulose}

In nature, cellulose is found in the cell walls of plants, including trees, and it has a vital role in providing mechanical strength and structural support [32]. Plant-based cellulose is accompanied by hemicellulose, lignin, pectin, and other substances [33]. Besides plants, certain bacteria, algae and fungi produce cellulose [34].

Cellulose is a linear homopolysaccharide consisting of $\beta$-D-glucopyranose units linked by glycosidic $\beta(1-4)$ bonds. Each unit contains three hydroxyl groups. The long polymer chain has repeating elements, which have two anhydroglucose units (AGU) that form polymerized chain lengths of several thousand units [34]. Cellulose has an amphiphilic nature: the equatorial direction of a glucopyranose ring is hydrophilic, and the axial direction of the ring has a hydrophobic character (Figure 1). These characteristics play a 
significant role in hydrophilic and hydrophobic interactions between cellulose molecules and other compounds in water [35-37].

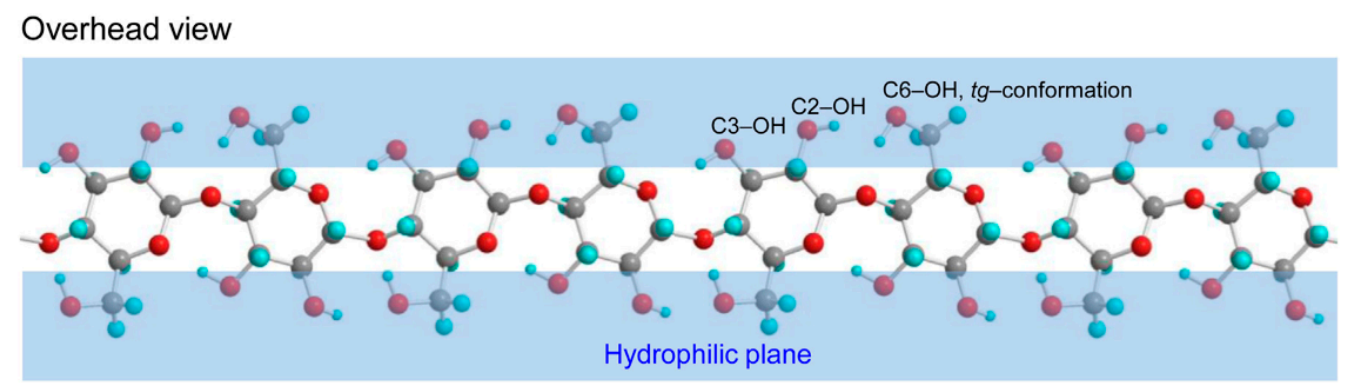

Side view

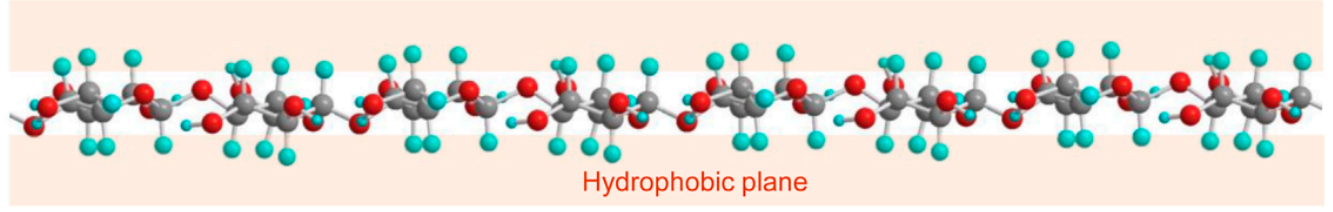

Figure 1. Hydrophilic and hydrophobic planes of cellulose marked with the primary C6-OH (with tg-conformation corresponding cellulose I crystalline structure), and secondary C2-OH and C3-OH groups in glucosyl unit. Reprinted with permission from [37].

Cellulose can be considered a semi-crystalline polymer with highly oriented crystalline domains coexisting with non-crystalline amorphous phases, which have a lower degree of order $[38,39]$. The cellulose crystalline domains have four major allomorphs (I, II, III and IV) based on molecular orientation. The most common allomorph found in nature is cellulose I and the most thermodynamically stable structure is established in cellulose II $[34,40]$. Cellulose I can have two sub-allomorphs, triclinic $\mathrm{I}^{\alpha}$ and monoclinic $\mathrm{I}^{\beta}$, which can be found alongside each other, and the ratio depends on the origin of the cellulose [34]. Cellulose $\mathrm{I}^{\alpha}$ dominates in primitive organisms, such as algae and bacteria, while cellulose $\mathrm{I}^{\beta}$ is found mainly in higher plants [41] and aquatic animals, such as tunicates [42]. Cellulose II can be modified irreversibly from cellulose I through alkaline treatment (mercerization) or by the cellulose dissolution process (regeneration) [34]. Cellulose III is obtained through liquid ammonia $\left(\mathrm{NH}^{3}\right)$, while cellulose IV is obtained through the heating of small crystallites in glycerol at $260^{\circ} \mathrm{C}$. Cellulose III can be reversibly formed from cellulose I, II or IV, and cellulose IV can be reversibly formed from cellulose I, II or III. The crystalline regions are strong, rigid, and quite inaccessible to water and most chemical reagents, whereas the amorphous regions are weaker and contribute to increased hydrophilicity and accessibility [42]. Physical, chemical, enzymatic or microbiological modifications of cellulose can lead to changes in its crystalline structure and result in new derivatives $[43,44]$.

Cellulose has a strong capability to form intra- and intermolecular hydrogen bonds in its establishment network, and these internal hydrogen bonds hinder the free rotation of the glucopyranose rings, which increases the stiffness of the cellulose chains $[45,46]$. Although cellulose has the same structural motif in each material, its degree of polymerization (DP, the number of monomer units in the polymer) and crystallinity (degree of packing order) can vary greatly [47]. DP and crystallinity depend on the origin and treatment of the raw material [34]. Insights of the physical properties and morphological structure of single polymeric chain, such as chain length or degree of crystallization, can be investigated via X-ray, optical and electron-microscope imaging, or chemical and physical analysis methods [48]. 


\subsection{Nanocellulose}

The production of nanoscale cellulose has captured great attention due to its biodegradability, renewability, high mechanical properties and low density [49]. Nanocellulose, as a general term, applies to a wide range of nano- and micro-sized fibrils and crystalline particles (sometimes also referred to as whiskers). Different terminologies have been used for the various types and forms. Because of inconsistency in terminology, the Technical Association of the Pulp and Paper Industry (TAPPI) has proposed standard terms for various types of nanocellulose based on their size and form (Table 1). Nanocellulose can be processed from plant-derived cellulose, but it is also found natively in tunicates and bacteria. The feedstock used in nanocellulose manufacture is highly important, as it affects the properties and size of the extracted cellulose [42].

Table 1. Standardize terms for cellulose nanomaterials according (I) TAPPI/W123021 [42], and [II] cellulose nanomaterials review: structure, properties, and nanocomposite [50]. Each abbreviation have two alternatives. e.g., cellulose nanocrystal (CNC) and nanocrystalline cellulose (NCC).

\begin{tabular}{ccccc}
\hline NAME & ABBREVIATION & WIDTH & LENGTH & L/D RATIO \\
\hline $\begin{array}{c}\text { Cellulose } \\
\text { nanocrystal }\end{array}$ & CNC (NCC) & $\begin{array}{l}\text { (I) } 3-10 \mathrm{~nm} \\
\text { (II) } 3-20 \mathrm{~nm}\end{array}$ & (II) $50-500 \mathrm{~nm}$ & (I) $>5$ \\
\hline $\begin{array}{c}\text { Cellulose } \\
\text { nanofibril }\end{array}$ & CNF (NFC) & $\begin{array}{l}\text { (I) } 5-30 \mathrm{~nm} \\
\text { (II) } 3-100 \mathrm{~nm}\end{array}$ & (II) $0.5-2 \mu \mathrm{m}$ & (I) $>50$ \\
\hline $\begin{array}{c}\text { Cellulose } \\
\text { microcrystal }\end{array}$ & CMC (MCC) & $\begin{array}{l}\text { (I) } 10-15 \mu \mathrm{m} \\
\text { (II) } 10-50 \mu \mathrm{m}\end{array}$ & (II) $10-50 \mu \mathrm{m}$ & (I) $<2$ \\
\hline $\begin{array}{c}\text { Cellulose } \\
\text { microfibril }\end{array}$ & CMF (MFC) & $\begin{array}{l}\text { (I) } 10-100 \mathrm{~nm} \\
\text { (II) } 10-100 \mathrm{~nm}\end{array}$ & $\begin{array}{l}\text { (I) } 0.5-50 \mu \mathrm{m} \\
\text { (II) } 0.5-10 \text { 's } \mu \mathrm{m}\end{array}$ & \\
\hline
\end{tabular}

The biosynthesis of cellulose forms continuous microfibrils, which self-organises fibre bundles with crystalline and amorphous domains [22]. The term cellulose microfibrils (MFC) was first introduced in 1983 by Turbak et al. [51] when he and his co-workers developed a new method to prepare highly fibrillated cellulose from wood fibres by highpressure homogenization treatment in water. The extraction of cellulose microfibrils require great precision in order to minimize damage to the fibrillary structure and to keep the long axial length of the microfibrils to preserve the large aspect ratio. The other native features of the cellulose, such as crystallinity and degree of polymerization, must also be secured [52]. An ideal production method should produce large amounts of high-quality material with low energy consumption. To meet these requirements, a number of pre-treatments can be used to improve the conversion efficiency. Different chemical, mechanical and enzymatic treatments are used for removal of non-cellulosic constituents and loosen the cell wall structure of the cellulose fibres to ease further processing [53].

Cellulose nanofibrils (CNFs), or their microfibril bundles, are typically produced using a variety of mechanical processes, including grinding/refining, high-pressure homogenization, cryocrushing, high-intensity ultrasonic treatments, electrospinning, steam explosion and microfluidization [50,54]. Chemical modification methods such as TEMPO mediated oxidation [55], ammonium persulfate oxidation [56], carboxymethylation [57] and cationization [58] have also emerged as promising methods for CNF production.

'Rod-like' cellulose microcrystals (MCC) and cellulose nanocrystals (CNC) can be obtained from different cellulosic sources such as wood, cotton, bacteria or tunicates with varied dimensions $[59,60]$. Their dimensions depend on the origin of the cellulose fibre or fibril and the employed conditions. Isolated nanoscale fibres or crystals from natural fibres show much higher strength and stiffness in comparison to the original source [49]. The elastic moduli of solid wood, single pulp fibre, microfibrils and crystallites have been measured at 10, 40, 70 and $250 \mathrm{GPa}$, respectively [61]. Cellulose nano- and microcrystals can be produced from nano- and microfibrils by applying chemical treatments 
(mainly acid) or mechanical processes, which break hydrogen bonds in amorphous regions while crystalline domains remain untouched $[62,63]$.

When producing nanocellulose, the drying process is a critical step. As cellulose is hydrophilic, hydrogen bonds can be formed during drying, leading to an irreversible agglomeration known as hornification [64]. This changes the size of nanocellulose, as well as its unique characteristics. The formation of additional hydrogen bonds correlates with the amount of water removed and does not depend directly on temperature $[65,66]$. A wide variety of drying methods, such as freeze drying, supercritical drying, atomization drying and spray drying, have been developed to prevent aggregation [54].

\section{Dissolution of Cellulose}

\subsection{Cellulose Mercerization}

Cellulose is hard to dissolve in most common solvents due to the large quantities of inter- and intra-molecular bonds and van der Waals forces [67]. In addition, hydrophobic interactions that contribute to the stability of cellulose polymers also play a role in dissolution kinetics [43,68]. The melting temperature of cellulose is above the stage of degradation, meaning that cellulose degrades before it liquifies $[8,45]$. Since cellulose cannot melt, as it is not thermoplastic, reshaping the cellulose structure and breaking the strong intraand intermolecular hydrogen bond network requires the dissolution of cellulose [69]. The amorphous regions of cellulose have higher free energy, and they are more easily accessed by solvents [35]. Hence, prior to dissolution, the crystalline domains of cellulose are often transformed into disordered regions by different activation processes [70].

Mercerization is widely used alkaline treatment for cellulose modification and was devised already in 1844 by John Mercer [71]. In the mercerization process, native cellulose fibres are immersed in an aqueous $\mathrm{NaOH}$ solution. When the fibres come in contact with strong alkali solutions their properties changes. An initial swelling by the alkali ions occurs in the amorphous regions between the fibrils. The alkali ions will then penetrate further into the crystalline regions which generates a more open and reactive alkaline cellulose structure (Figure 2) [72].

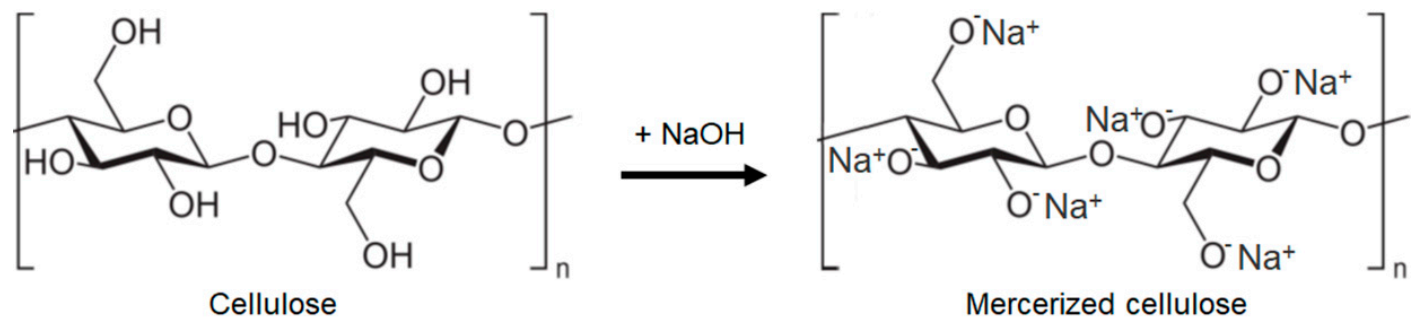

Figure 2. Mercerization (sodium hydroxide treatment) of cellulose in natural fiber cell. Reprinted with permission from [72].

The mercerization process can be used as a pre-treatment to efficiently lower the degree of polymerization, disrupt the crystalline structure of cellulose, and ultimately promote the accessibility of dissolution practices [73]. The mercerization process also provides better mechanical properties, shine, smooth surface, dimensional stability and improved dye intake for the cellulose fibres [39]. In addition, on the molecular level the mercerization changes the crystalline structure of cellulose from cellulose I to cellulose II (Figure 3) [41]. There are conflicting views regarding the mechanism on how cellulose I, which have parallel configuration, transforms to antiparallel configuration without undergoing a fully dissolved state [39]. Contrary to this, it is clearly noted that temperature change can affect the mercerization efficiency [74]. 


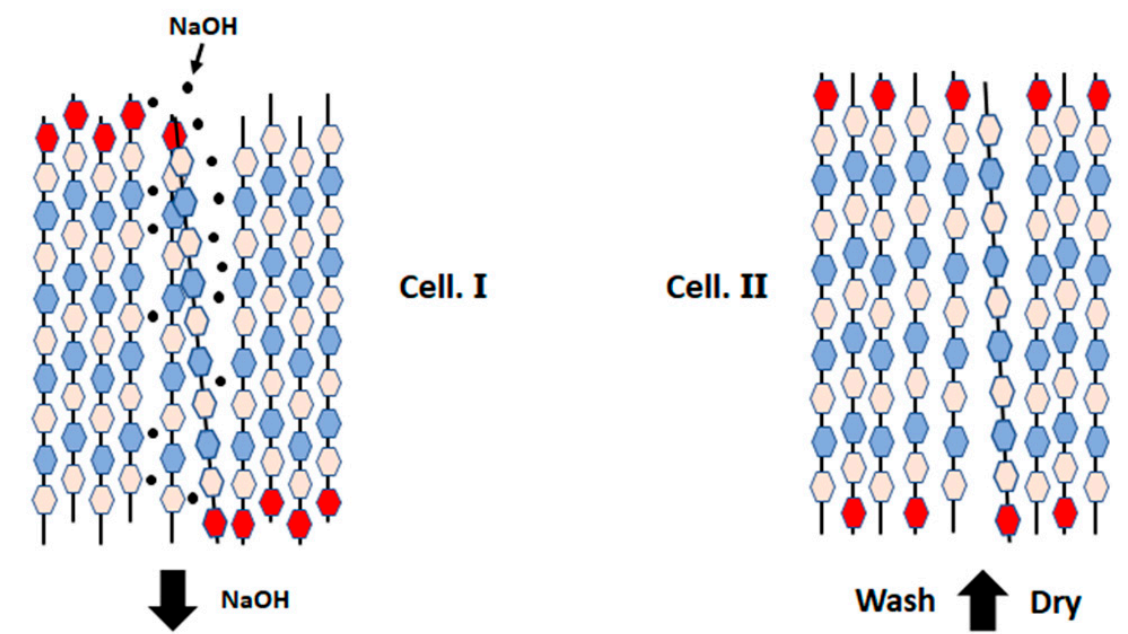

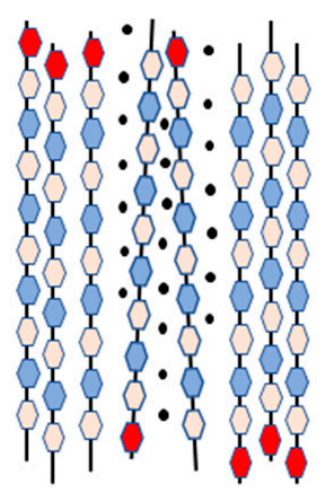

Cell. I + Na-Cell. I

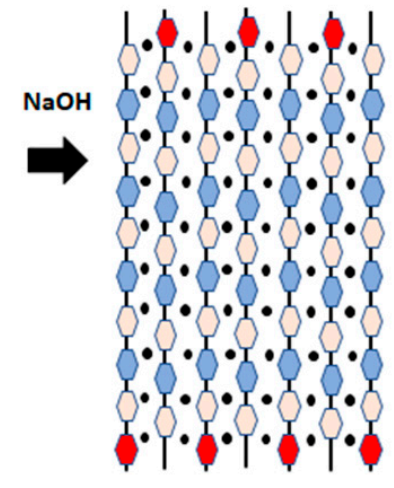

Na-Cell. I

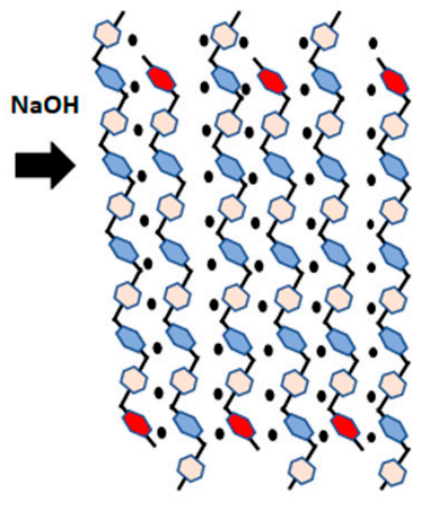

Na-Cell. II

Figure 3. Schematic presentation of parallel-packed cellulose I converting to antiparallel-packed cellulose II during mercerization. Reaction scheme adapted from [75].

\subsection{Solvents for Cellulose}

Many efficient cellulose dissolution solvent systems are currently in use (Figure 4). The most used industrial scale solvent systems are the viscose and lyocell processes. Other processes such as $\mathrm{DMAc} / \mathrm{LiCl}$, cellulose carbamate, aqueous $\mathrm{NaOH}$-with additives, ionic liquids and deep eutectic solvents (DES) are in different stages of technological maturity and constantly developed further.

Some of the solvent systems developed especially in past have a negative impact on the environment [67]. Therefore, finding new ways to effectively dissolve cellulose and produce regenerated cellulose materials in an environmentally friendly way has recently been of major interest within research on cellulose refining technologies [76-78].

Cellulose solvents can be divided into two categories: derivatising and non-derivatising solvents. Non-derivatising solvents physically dissolve cellulose by breaking hydrogen bonds. Therefore, these solvents only change intermolecular interactions. Non-derivatising solvents can, more specifically, be divided into aqueous and non-aqueous sub-groups. Derivatising solvents convert cellulose polymers into soluble intermediates by derivatizing cellulose's hydroxyl groups. These solvents can form hydrolytically unstable, organosoluble cellulose intermediates, such as ethers, esters, or acetal derivatives [79]. 


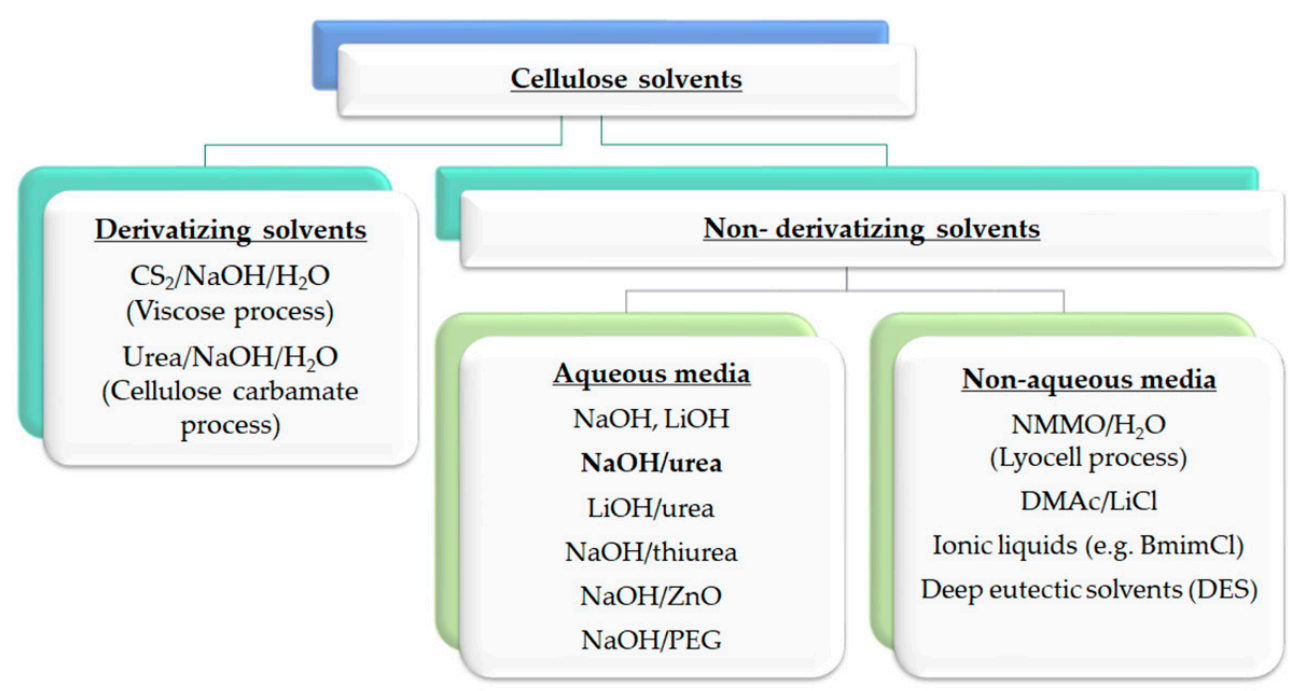

Figure 4. Classification of cellulose solvents. The overview includes the most commonly used and newly researched solvents.

\subsection{Derivatising Solvents}

The most widely used and important industrial-scale method to dissolve and process cellulose is the viscose process, which is used to create viscose fibres and cellophane films $[39,67]$. During the viscose process, cellulose, often from wood pulp or cotton linters, is treated with sodium hydroxide and then with carbon disulfide, resulting in a product called cellulose xanthate. The alkaline cellulose xanthate forms a thick solution, which is forced through small openings into acid, where it will eventually coagulate as regenerated cellulose [40]. In the traditional viscose process, the usage of carbon disulfide in the solution is a cause of environmental pollution, and the development of volatile sulphur-containing compounds (e.g., $\mathrm{H}_{2} \mathrm{~S}, \mathrm{COS}$ ) requires complex recovery technologies [80-82].

The cellulose carbamate process is an attractive, more sustainable alternative to the viscose process, and it can utilize conventional viscose spinning equipment [83-85]. Cellulose carbamate is a cellulose derivate with carbamate groups substituted on the hydroxyl groups along chain molecules [86], and it can be prepared through various routes. In the conventional processes, the formation of cellulose carbamate begins when cellulose is treated with urea at a temperature above its melting point in an alkali medium with an organic solvent, such as xylene (the CarbaCell process) or toluene $[87,88]$. Other ways to produce cellulose carbamate include using supercritical $\mathrm{CO}_{2}[89,90]$, microwave heating [83,91], electron beam irradiation [92], liquid ammonia [88,93] or deep eutectic solvents [94] as part of the manufacturing processes. Recent developments in process operation, increased understanding of physical chemistry, and lower cost of raw materials have increased the competitiveness of cellulose carbamate processes. Further improvements need to be focused on handling the rigorous processing conditions (e.g., pre-treatments, reaction times, temperatures and specific equipment requirements) and efficient chemical recycling $[83,88]$.

\subsection{Non-Derivatising Solvents}

\subsubsection{Non-Aqueous Solvents}

The Lyocell process, in commercial use since 1991, allows for the dissolution of cellulose without derivatisation, complexation or special activation [40]. In the Lyocell process, cellulose pulp is dissolved in an aqueous solution of N-Methyl-morpholine $\mathrm{N}$-oxide (NMMO). Using spinnerets, the formed solution is extruded across an air gap into a coagulation bath containing water, which works as a non-solvent. While NMMO is separated by extraction, the cellulose fibres are regenerated in the water by precipitation [95]. The Lyocell process is considered to be a more environmentally friendly option than the viscose process because NMMO hydrates are non-toxic to the environment [96]. However, the 
NMMO also has limited thermal stability, due to which a variety of additional by-products may appear [97,98].

The dissolution of cellulose using organic solvents in combination with salts, such as in the case of the $\mathrm{DMAc} / \mathrm{LiCl}$ solvent system, has also captured both industrial and academic interest [99-102]. The DMAc/ $\mathrm{LiCl}$ solvent system has been widely applied, and it can also dissolve cellulose with high molecular weight without noticeable degradation [103]. The drawbacks of this process are the high cost and difficulties with recycling the solvent due to its low volatility, which limits its further development for commercial applications $[68,104]$.

Ionic liquids have risen as alternative, environmentally friendly and powerful solvent systems for shaping cellulose [68,105]. What makes ionic liquids interesting is that they are organic salts that exist as liquids at relatively low temperatures $\left(<100{ }^{\circ} \mathrm{C}\right)$ and can obtain good thermal stability, low melting point and low vapor pressure [106,107]. Ionic liquids such as 1-butyl-3-methylimidazolium chloride can dissolve refined or natural cellulose without causing derivatisation $[108,109]$. One emerging process, which is currently in its pilot scale and utilizes ionic liquids to dissolve cellulose, is the Ioncell process $[110,111]$. The Ioncell pulp (Ioncell-P) method can be used to produce high-purity cellulose from bleached paper-grade birch kraft [112], and Ioncell fibres (Ioncell-F) can be formed using the same dry-jet wet spinning technique as the Lyocell-NMMO system [113]. One of the current challenges with the commercialisation of the Ioncell process is recovering the solvent from the coagulation bath without impairing its solvation power. Therefore, more research is still required to improve the recyclability and long-term chemical stability of the solvent system without compromising energy efficiency $[80,112,113]$.

Deep eutectic solvents (DESs) share many characteristics and physiochemical properties with ionic liquids, but they are generally considered easier to prepare with high purity at low cost $[81,114]$. DESs are composed of two or three often cheap and safe chemicals that consist of a hydrogen bond donor and a hydrogen bond acceptor $[115,116]$. These components are capable of self-association and form a eutectic mixture with a melting point lower than that of each individual component. In most cases, DESs are liquids between room temperature and $70{ }^{\circ} \mathrm{C}$ [115]. One promising DES system can be formed by combining choline chloride $(\mathrm{ChCl})$ and urea [116]. The benefits of this DES system are the good availability of chemicals and their low melting point. However, based on current knowledge, the solubility of cellulose in DESs is far below that of ionic liquids or in the Lyocell process, but it can be improved in the future $[81,115]$.

\subsubsection{Aqueous Solvents}

It was discovered already in 1930s that by combining some additives to the aquatic $\mathrm{NaOH}$ or $\mathrm{LiOH}$ solution, the solubility of cellulose can be improved, and cellulose can be dissolved [117-121]. Such additives include urea [122-124], thiourea [13,125-127] zinc oxide $(\mathrm{ZnO})[128,129]$ and poly(ethylene glycol) (PEG) $[130,131]$. Although these additives improve cellulose solubility, the role of the additives has not been fully understood. It is suggested that e.g., in aqueous $\mathrm{NaOH}$-urea dissolution process, the hydroxyl $\left(\mathrm{OH}^{-}\right)$anion breaks the inter- and intra-molecular hydrogen bonds of the cellulose, while sodium $\left(\mathrm{Na}^{+}\right)$ ions stabilize the hydrophilic hydroxyl groups and urea stabilizes the hydrophobic part of cellulose [132]. Rapid dissolution of cellulose occurs in conditions such as aqueous $7 \mathrm{wt} \%$ $\mathrm{NaOH} / 12 \mathrm{wt} \%$ urea solution, which has been pre-cooled to $-12{ }^{\circ} \mathrm{C}$ [118]. Here, similar to many other dissolution processes, degree of dissolution is related to molecular weight, crystallinity and applied conditions [133]. Therefore, having comprehensive understanding of structure and property relationship of dissolution mechanisms will be essential and ease commercial development for the $\mathrm{NaOH}$-urea solvent system in industrial scale. These solvent systems are particularly interesting since they are cost-effective, non-volatile, they possess of low environmental toxicity, and they show great potential when it comes to the usage of cellulose from agricultural and forestry wastes $[41,77,134]$. The only apparent disadvantage of these methods is the need to involve freezing-to-thawing [135], which requires specific cooling equipment. 


\section{All-Cellulose Composites}

\subsection{Raw Materials for the ACC}

Natural fibres are divided into three categories: plant fibres, animal fibres and mineral fibres (Figure 5). Plant fibres are the most used in conventional composite processing only as a reinforcement. All plant fibres contain cellulose, while animal fibres are made from proteins [136].

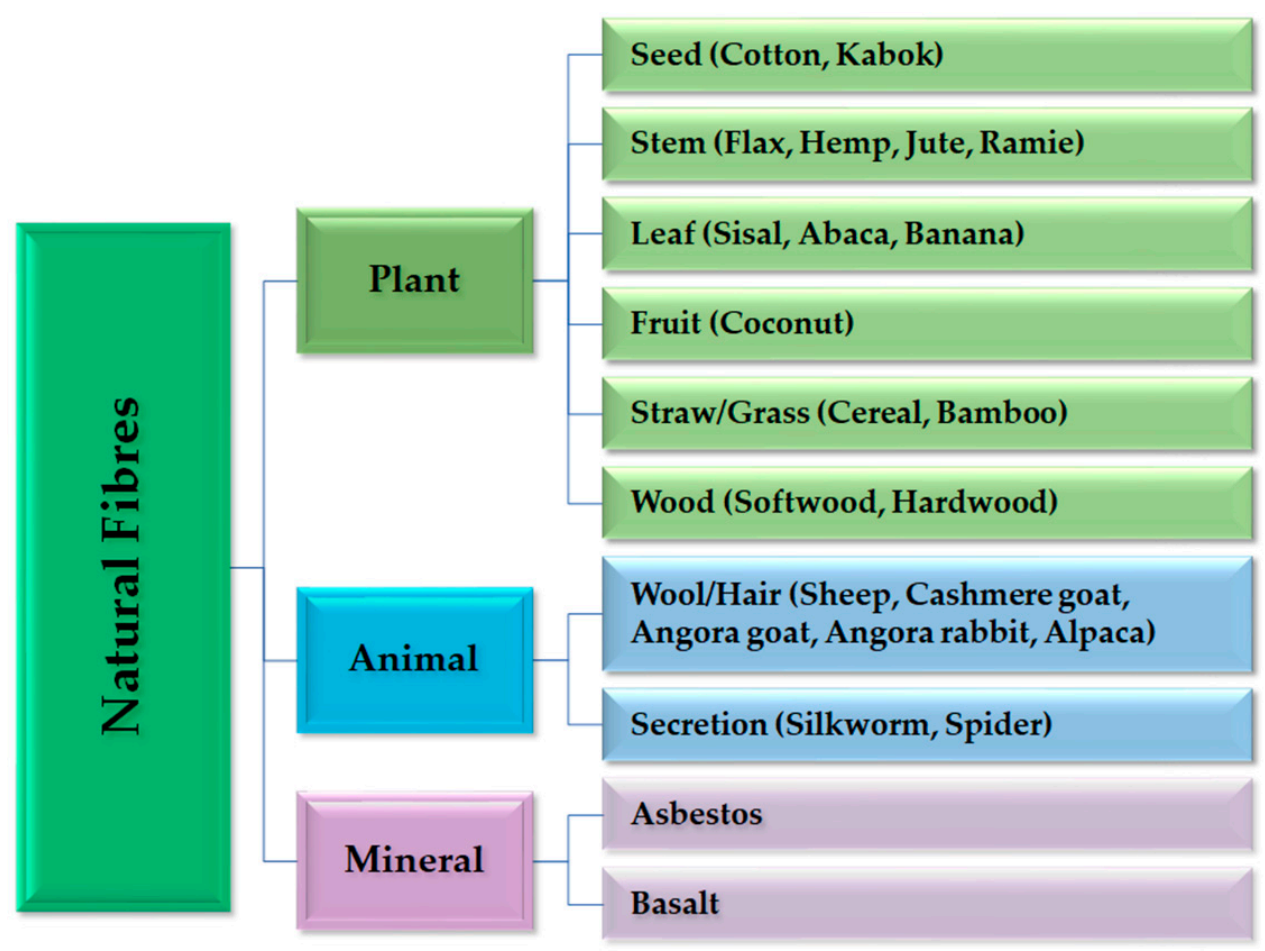

Figure 5. Classification of natural fibres with examples of their origin. This overview excludes nanosized cellulose fibrils and cellulose crystals that are found in bacteria and tunicates.

Plant-based cellulose is considered one of the most promising substitutes for petroleumbased raw materials [137]. The fibre structure and characteristics depend on and vary with the plant species, age, growth location, climate and part of the plant. Therefore, one of the main challenges with plant fibres is the large variation in their properties $[42,138]$. Fibres are extracted from trees using either chemical or mechanical methods. The characteristics of wood fibre depend somewhat on the processing method used, but mostly on the anatomy of the wood material in the particular tree species. Wood fibres can be divided into softwoods, such as spruce and pine, and hardwoods, such as birch and eucalyptus. Both can be used to create pulp or dissolving pulp. Dissolving pulp has a higher cellulose content and lower hemicellulose content compared to paper-grade pulp, and therefore it is used more commonly in upgraded and high-quality products. Two widely used commercial production methods for dissolving pulp are pre-hydrolysis kraft (PHK) and acid sulphite (AS) [98]. Pulp can also be produced from cellulosic waste with new innovative technologies $[139,140]$.

Man-made cellulose fibres, such as viscose or lyocell, are developed from pulp or dissolving pulp. They are mainly used in the textile industry [141] but are also important materials used in composite manufacturing [142]. Textile-reinforced composites typically have high strength-to-weight and stiffness-to-weight ratios, which can improve the mechanical properties of the composites [143]. Cellulose-based textiles are renewable, but at the same time, textile industry as a whole (including the unsustainable cotton production) are one of the largest contributors to harmful environmental effects on Earth, and it also generates large amounts of textile waste $[144,145]$. Therefore, the industry is searching for 
more sustainable plant-based fibres to meet the demands of current standards, where the focus is on waste reduction, production efficiency, durability, water saving, recycling and closed-loop production [145].

The frontrunner in the field of sustainable fibre production, Lensing AG, produces wood pulp-based fibres called EcoVero ${ }^{\mathrm{TM}}$, the production of which consumes less water and releases less emissions than generic viscose production, and their Tencel ${ }^{\mathrm{TM}} \times$ Refibra $^{\mathrm{TM}}$ fibre contributes to the circular economy by using an efficient closed-loop process [146,147]. Kuura-fiber is another new pulp-based wood fibre, which shares similar sustainable values, and it is currently on pilot scale production by Metsä Fibre in Äänekoski bioproduct mill, Finland [148]. Recycled textiles and agriculture waste are used in a fibre technology called Infinna $^{\mathrm{TM}}$, created by the Infinited Fiber company [149], and recycled cotton fibres have been transformed into sustainable yarn by Haksa Textiles [150]. More recently, new types of wood fibre have been mechanically produced without using harmful chemicals or solvent systems. In Spinnova's innovative fibre process, the pulp is mechanically refined and transformed into spinning-ready fibre suspension without dissolution or regeneration [151].

These novel textile fibres offer versatile reinforcement choices for a more sustainable composite industry. Recently, biocomposites [152] and all-cellulose composites [153] have also been created using denim waste.

\subsection{Biocomposites}

Biocomposites have at least one of their constituents (either reinforcement or matrix) derived from biomass [154]. Already in the early 1940s Henry Ford created natural fibre reinforcement biocomposites using soy-based plastics to reduce the weight of the cars [155]. However, it was not until recently that bio-based automotive parts caught popularity among the car manufacturers due to increasing emission control and sustainability concerns [156].

The most commercially important biocomposites are made by combining man-made and biobased sources. Commonly, matrices are petrochemically derived thermoplastic polymers, such as polypropylene or polyamide, or thermoset polymers, such as unsaturated polyester or epoxy resins; meanwhile, the reinforcement is formed using a variety of biobased sources, such as natural cellulosic plant-based fibres or wood pulp [157,158]. The use of wood and plant fibres in composites is motivated not only by their sustainability characteristics, but also their good performance, low cost, low density, safe handling, high electrical resistance, good acoustic insulation and the fact that they do not require moulding equipment $[159,160]$. A major drawback of natural plant-based fibres compared to man-made fibres is the hydrophilic nature of cellulose. Water absorption by cellulose fibres can result in aging, poor mechanical properties and reduced dimensional stability of the composite. Plant fibres also naturally have poor fire resistance, and they degrade when heated to over $200{ }^{\circ} \mathrm{C}$. They are also easily susceptible to biological degradation $[138,160]$.

Nanocellulose, which is used as a raw material especially for ACNC, can be obtained by two approaches (i) top-down and (ii) bottom up. The top-down approach involves the disintegration of lignocellulosic biomass into nanoscale cellulose. In the bottom-up approach nanoscale cellulose can be produced via fermentation of low weight sugars by cellulose-producing bacteria, such as from the Acetobacter species. This type of nanoscale bacteria (BC) is pure cellulose and does not include hemicellulose, lignin, or pectin [161]. When cellulose-based composites are produced from less purified sources, such as wood pulps or other plant fibres, hemicellulose and lignin are always present to some degree, and these can act as impurities which often results impairing properties of the composite [30].

\subsection{Matrix-Reinforcement Compatibility}

Two main components forming a composite are the reinforcement and the matrix, where reinforcement gives strength and stiffness to the composite [162], and the matrix acts as a binder for the reinforcement and transfer external loads along the reinforcing 
fibres $[138,163]$. Compatibility between reinforcement and matrix depends on fibre dimensions, microstructure, and morphology; as well as the mechanical, physical, chemical, and thermal characteristics of the different constituents present in the interfacial zone. During composite manufacturing the changes in the constituent's properties or structure also influence interfacial interactions. For instance, if the fabrication process involves cooling from high temperatures to ambient temperature, the difference in the expansion coefficients of two components might lead to thermal stress and can be the cause of plastic deformation and impaired matrix-reinforcement compatibility [4].

The main performance challenge when using conventional biocomposites is the poor interfacial adhesion between the hydrophilic plant-based reinforcement and the hydrophobic matrix phases, which can lead to weakened mechanical performance, as well as problems in recycling due to the heterogeneous mixture $[159,164]$. One way to overcome weak compatibility and recyclability challenges in conventional composites and biocomposites is to create single-polymer composite (SPC), where similar or identical polymers are used for both the reinforcement and the matrix [165]. The polymers can be of renewable or nonrenewable origin [166]. Non-renewable SPCs are, e.g., all-polyethylene composites [167] and all-propylene composites [164], whereas renewable fully cellulosic SPCs are bio-based. Basically, all-cellulose composites are reviving old vulcanized fibre technology where a cellulosic material is converted into a unique SPC laminate product $[168,169]$.

\section{Production of ACC}

\subsection{Processing Routes}

There are two main ways to produce ACCs [102,170-173]. The first method is the one-step method. It is based on the partial dissolution of cellulosic materials, where the same raw material is used to create both reinforcement and matrix (Figure 6) [6,14]. This type of composite can also be called a self-reinforcing composite [172]. Here, the chosen cellulose solvent system will partially dissolve the surface or weaker regions of the reinforcement fibres, and the dissolved cellulose will form a matrix surrounding the initial fibre structure during its precipitation. Meanwhile, the core of the reinforcing fibres maintains its original structure and chemical crystallinity, which has a reinforcing effect on the composite [131]. One of the great benefits of this approach is that interfaceless composites can be prepared where the boundaries between reinforcement and matrix are indefinite between the phases [14]. In addition, the undissolved fibre content of the composite can easily be controlled by changing the dissolution time [102].

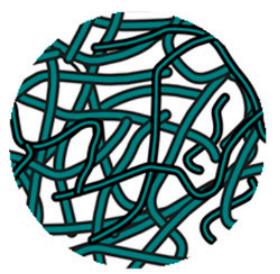

Fiber

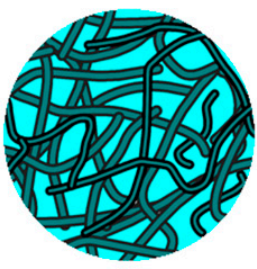

Fiber + $\mathrm{NaOH}-$ urea solvent

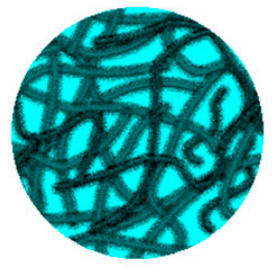

Partly dissolved fiber structure + $\mathrm{NaOH}$-urea solvent
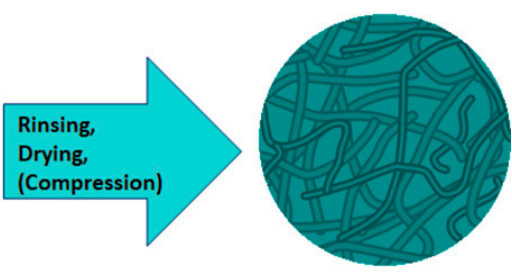

All-cellulose composite

Figure 6. One-step method of creating all-cellulose composite with $\mathrm{NaOH}$-urea solvent system.

Another way to manufacture ACCs is the two-step method, in which a high-strength reinforcing fibre is impregnated with a solution containing dissolved cellulose, which forms a matrix around the fibre structure after the regeneration process. This way, the composite is formed from solid cellulose and dissolved cellulose, which are chemically bound to each other at a specific temperature, pressure and curing time. The advantage of this method is that the fibre content of the composite is easily controlled by changing the mixing ratio [102], and the processing method is beneficial for composite bulk production [173]. 


\subsection{Factors Influencing Composite Properties}

The mechanical properties of composites are influenced by several factors (Figure 7). The source of the raw materials is a crucial element. Amongst the cellulose-based natural fibres, flax, hemp and ramie fibres are having the highest tensile strength (345-1830 MPa, 550-1110 MPa, 400-938 MPa respectively) and the highest specific Young's moduli $\left(18-53 \mathrm{GPa} / \mathrm{g} \mathrm{cm}^{-3}, 39-47 \mathrm{GPa} / \mathrm{g} \mathrm{cm}^{-3}, 29-85 \mathrm{GPa} / \mathrm{g} \mathrm{cm}^{-3}\right.$ respectively) [174]. However, there are much variability within literature. The average modulus of tensile strength of regenerated cellulose fibres has been measured to have lower values than flax fibres, but fracture toughness of regenerated cellulose fibres was superior to flax [175]. In comparison with natural fibres, the man-made cellulose fibres also show better homogeneity in terms of their structure and mechanical properties [176].

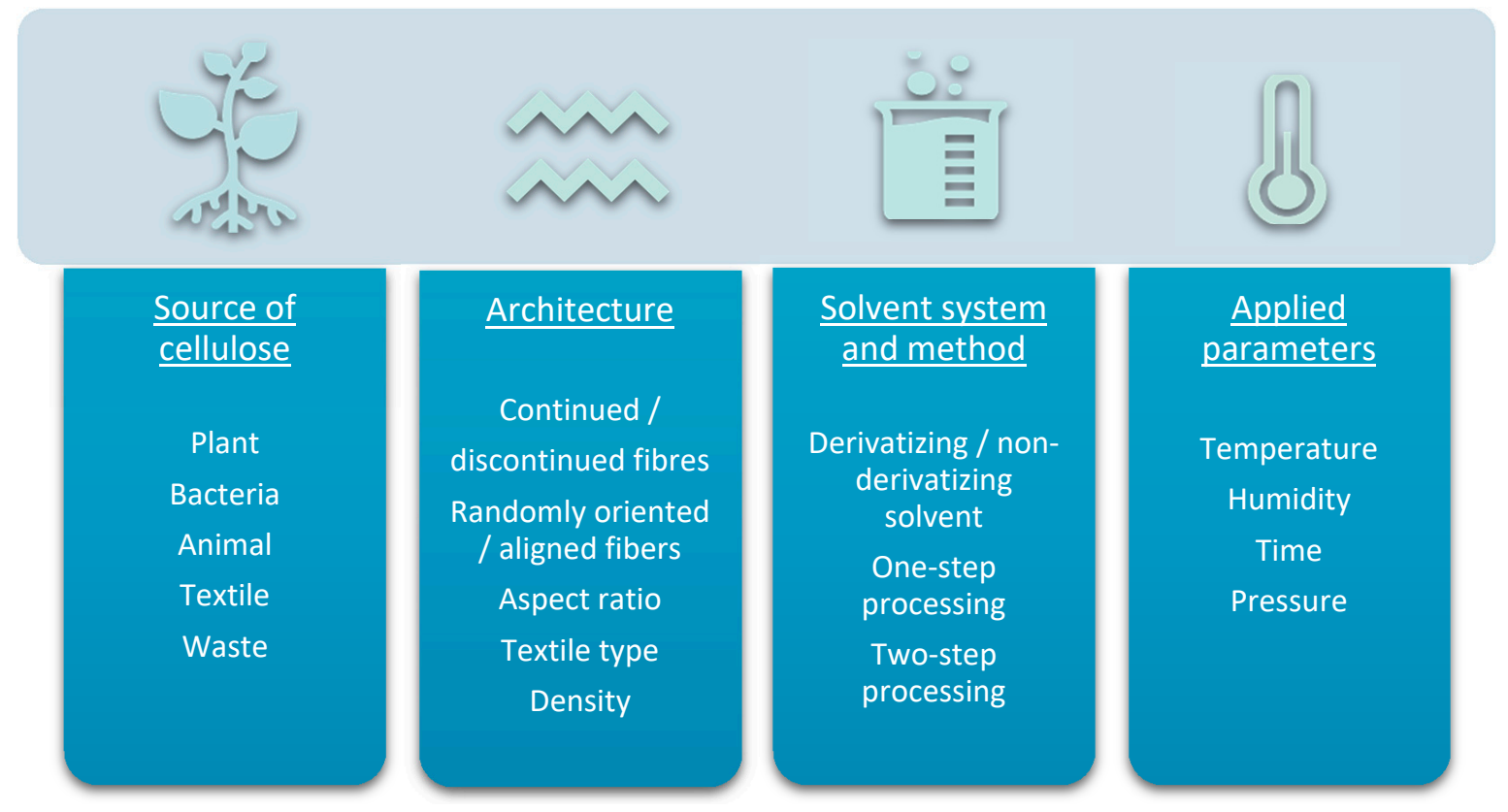

Figure 7. Physical and chemical properties of ACC depend on raw materials (and their compatibility), architecture of the composite, chosen solvent system, processing method and applied experimental conditions.

Nanocellulose as the raw material can improve tensile modulus of the composites and can be used in the production of high-performance composites. Methods and values regarding the properties of nanocellulose varies in the literature, but generally smaller specimens tend to have higher density and higher strength [177]. Therefore, it is not unexpected that a nanofiber-based ACC sheet has been proven to be 11 times stronger than a similar sheet from microfiber, when same raw material (canola straw) and dissolution method $(\mathrm{DMAc} / \mathrm{LiCl})$ was used [178]. Besides the fibre size, also the source of the raw material has a huge influence on the ACC properties. Comparative research, where two different forms of cellulose nano-whiskers were used to produce the ACC, concluded that tunicate cellulose enhanced the mechanical properties of the composites to a greater degree than cotton derived nanocellulose [179].

Volume fraction, aspect ratio and adhesion between reinforcement and matrix are highly relevant for the creation of the composites $[39,138]$. High cellulose content in reinforcement and good fibre dispersion will promote better mechanical performance and interfacial bonding in natural fibre composites [174,180]. In general, the strength of an ACC increases up to a certain limit proportionately with increasing filler fraction [102]. After certain limit the increase of filler content will not enhance properties, but rather decrease them. When the maximum content is achieved, the strain to failure of the composite decreases, leading to an embrittlement of the material [179]. In addition, when the 
reinforcement content is very high, a large number of voids might appear, which is seen as low density [173].

Better compatibility between matrix and reinforcement has been researched for the two-step processed ACC when there was higher cellulose content in matrix constituent. According to Duchemin [181], it would be beneficial to have a high cellulose content in the solution of dissolved cellulose to minimize matrix shrinkage during regeneration, which helps to maintain good bonding between the matrix and the reinforcement. On the other hand, solutions with high cellulose content have high viscosity, which makes their impregnation challenging. Very low cellulose concentrations, in turn, lead to inconsistent cellulose network formation. The possible formation of pores or voids after regeneration leaves the ACC structurally heterogeneous and mechanically weak. Similarly, the use of cellulose reinforcement with a high degree of crystallinity makes the interfacial bonding poor, as the particles are less accessible to the hydroxyl groups of the more open-structured matrix cellulose. Therefore, the degree of shrinkage for dissolved and undissolved cellulose will vary during the drying process, which can also create unwanted interfacial voids. The negative impact of internal cracking can be avoided and controlled to some degree by applying light pressure during drying [182]. One way to improve mechanical performance is to apply additional chemical modification. For instance, alkali treatment can fill the cracks and voids between reinforcement and matrix, which contributes to improving the interface and the quality of the composite [183].

The engineered architecture and alignment of the reinforcing fibres have a major impact on the mechanical properties of the composite. Fibres can be continuous or discontinuous, aligned randomly or unidirectionally, and fabric architecture can be nonwoven, woven or knitted [2]. ACC with uniaxial reinforcement offer generally higher stiffness and strength along the fibre direction, compared to randomly reinforced composites [102,184]. Lyocell fabric, with modified structure, had massive improvement in microstructure of ACC. Here, the fabric was modified by removing weft yarn to create unidirectional effect. Compared to regular fabric, this modified structure helped to bind the undissolved cellulose fraction properly, leaving almost no voids. This significant reduction of internal void content generated ACC with better tensile and flexural properties than those most conventional biocomposites [185].

ACC can be produced by using multiple different solvent systems and manufacturing methods. Comparative studies on how different solvent systems affect the properties of ACC can be challenging to carry out reliably, when each solvent system still need to be optimized individually. Notwithstanding, Pullawan et al. (2014) found out that LiCl based matrix performed better than $\mathrm{NaOH}$ / urea-based system for ACNC production regarding tensile strength and modulus [179].

Many of the process variables in ACC production, such as temperature, humidity, pressure and dissolution time depend on chosen solvent system. Generally, the strength of the fibres increases with increasing moisture content and decreases as temperature increases [186]. When producing ACC-based aerogels, a major influential factor is the drying method-freeze-drying, $\mathrm{CO}_{2}$ drying or vacuum drying-since it determines the resulting morphology of the ACC [187]. Adak and Mukhopadhyay [185] have researched the effect of applied pressure on the structure and properties of ACCs. According to the study application of pressure during composite manufacturing, controlled shrinkage and void formation and improved adhesion. This significantly contributed to better tensile and flexural properties of ACC laminates. In another study related to pressure, the elongation at break of cotton fabricated ACC decreased and the tensile modulus increased with increasing pressure of hot press. In the same study on hinoki lumber based ACC, a diverse outcome was obtained: applying $10 \mathrm{MPa}$ and $5 \mathrm{MPa}$ pressure gave higher tensile modulus than when applying a pressure of $15 \mathrm{MPa}$. The decrease in tensile modulus at $15 \mathrm{MPa}$ can be related to observed cracks in formed composite [188].

The optimal immersion and dissolution time depends on the characteristics and volume of the cellulose and chosen solvent system; therefore, the dissolution time needs 
to be tailored for each composite. Ideally, in partial dissolution, when the immersion time in the solvent increases, the non-crystalline regions form as long as the dissolution process is active and re-solidified parts turn into amorphous regions [6]. When higher amount of cellulose is dissolved, the formation of internal voids will be reduced, due to improvement of intra and inter-laminar adhesion. The phenomenon has been reported in multiple studies $[6,185,189]$. The speed of regeneration also affects the properties of the composite, since slow precipitation develops a more ordered packing structure compared to fast generation [10]. Dormanns et al. [17] showed that the optimal dissolution time with $\mathrm{NaOH}$-urea solvent system was five minutes for rayon-reinforced laminate. An increased dissolution time led to a decrease in the tensile strength of the composite and caused microstructural changes to the crystallinity. Dissolution takes place initially in the amorphous regions between the crystallite parts, but with longer dissolution times, a more extensive breakdown occurs, and the fibres are weakened, which leads to a composite lacking strength. In another study, where dissolving pulp was used as raw material with $\mathrm{NaOH}$-urea solvent system, the optimal dissolution time was found to be only $30 \mathrm{~s}$, and longer dissolution times had minimal or no effect on the crystallinity or mechanical properties of the composite [171].

\section{Conclusions}

Due to increased awareness of environmental issues, there is a strong motivation to replace petrochemical-based materials with more sustainable alternatives. All-cellulose composites seem to be a good candidate, since they are renewable and biodegradable, have low toxicity and low density, and have good mechanical, optical and gas barrier properties. Whereas regular biocomposites suffer from fibre-matrix adhesion-related challenges, ACCs can overcome this problem by both matrix and reinforcement having the same or a similar chemical structure, which results in good interfacial compatibility.

Due to the presence of strong hydrogen bonds and the semicrystalline structure of cellulose, it cannot melt, and it is challenging to dissolve. Therefore, finding an effective solvent system to dissolve cellulose is a necessary step when developing ACC materials. Many conventional dissolving agents for cellulose generate by-products that are harmful to the environment during production; therefore, there is currently considerable interest in the research and development of sustainable cellulose solvents. Different raw materials, solvent systems, composite manufacturing methods, additives and processing parameters can lead to a variety of composite materials with unique properties.

Author Contributions: Conceptualization, writing, visualization and editing, E.-K.U.-T.; supervision and review, M.S. and A.H.; project administration and funding acquisition, E.-K.U.-T. and A.H. All authors have read and agreed to the published version of the manuscript.

Funding: The authors thank the Finnish Natural Resources Research Foundation, the Finnish Cultural Foundation, and the Magnus Ehrnrooth Foundation for co-funding the project leading to this work.

Institutional Review Board Statement: Ethical review and approval were waived for this study as it is solely based on literature reviewing previous investigations.

Informed Consent Statement: Not applicable.

Data Availability Statement: Review includes only public sources of data. Figure 1 is reproduced under the licence CC BY 4.0 at http:/ / creativecommons.org/licenses/by / 4.0 (accessed on 25 August 2021).

Acknowledgments: Henrik Heräjärvi from Natural Resources Institute Finland is gratefully acknowledged for a number of detailed advisory comments.

Conflicts of Interest: The authors declare no conflict of interest. 


\section{References}

1. Ekins, P.; Gupta, J.; Boileau, P. Global Environment Outlook: GEO-6: Healthy Planet, Healthy People; Cambridge University Press: Cambridge, UK, 2019.

2. Ramamoorthy, S.K.; Skrifvars, M.; Persson, A. A Review of Natural Fibers Used in Biocomposites: Plant, Animal and Regenerated Cellulose Fibers. Polym. Rev. 2015, 55, 107-162. [CrossRef]

3. Thomason, J.L. Glass fibre sizing: A review. Compos. Part A Appl. Sci. Manuf. 2019, 127, 105619. [CrossRef]

4. Chawla, K.K. Composite Materials: Science and Engineering; Springer: New York, NY, USA, 2013.

5. Soroudi, A.; Jakubowicz, I. Recycling of bioplastics, their blends and biocomposites: A review. Eur. Polym. J. 2013, 49, 2839-2858. [CrossRef]

6. Nishino, T.; Arimoto, N. All-Cellulose Composite Prepared by Selective Dissolving of Fiber Surface. Biomacromolecules 2007, 8 , 2712-2716. [CrossRef] [PubMed]

7. Wang, J.; Du, Z.; Lian, T. Extrusion-calendering process of single-polymer composites based on polyethylene. Polym. Eng. Sci. 2018, 58, 2156-2165. [CrossRef]

8. Nishino, T.; Matsuda, I.; Hirao, K. All-Cellulose Composite. Macromolecules 2004, 37, 7683-7687. [CrossRef]

9. Gindl, W.; Keckes, J. All-cellulose nanocomposite. Polymer 2005, 46, 10221-10225. [CrossRef]

10. Duchemin, B.J.; Newman, R.H.; Staiger, M.P. Structure-property relationship of all-cellulose composites. Compos. Sci. Technol. 2009, 69, 1225-1230. [CrossRef]

11. Ouajai, S.; Shanks, R.A. Preparation, structure and mechanical properties of all-hemp cellulose biocomposites. Compos. Sci. Technol. 2009, 69, 2119-2126. [CrossRef]

12. Abbott, A.; Bismarck, A. Self-reinforced cellulose nanocomposites. Cellulose 2010, 17, 779-791. [CrossRef]

13. Yang, Q.; Lue, A.; Zhang, L. Reinforcement of ramie fibers on regenerated cellulose films. Compos. Sci. Technol. 2010, 70, 2319-2324. [CrossRef]

14. Huber, T.; Bickerton, S.; Müssig, J.; Pang, S.; Staiger, M.P. Solvent infusion processing of all-cellulose composite materials. Carbohydr. Polym. 2012, 90, 730-733. [CrossRef] [PubMed]

15. Labidi, K.; Korhonen, O.; Zrida, M.; Hamzaoui, A.H.; Budtova, T. All-cellulose composites from alfa and wood fibers. Ind. Crop. Prod. 2019, 127, 135-141. [CrossRef]

16. Wei, Q.; Lin, H.; Yang, B.; Li, L.; Zhang, L.; Huang, H.; Zhong, G.; Xu, L.; Li, Z. Structure and Properties of All-Cellulose Composites Prepared by Controlling the Dissolution Temperature of a NaOH/Urea Solvent. Ind. Eng. Chem. Res. 2020, 59, 10428-10435. [CrossRef]

17. Dormanns, J.W.; Schuermann, J.; Müssig, J.; Duchemin, B.J.C.; Staiger, M.P. Solvent infusion processing of all-cellulose composite laminates using an aqueous $\mathrm{NaOH} /$ urea solvent system. Compos. Part A Appl. Sci. Manuf. 2016, 82, 130-140. [CrossRef]

18. Yousefi, H.; Nishino, T.; Faezipour, M.; Ebrahimi, G.; Shakeri, A. Direct Fabrication of all-Cellulose Nanocomposite from Cellulose Microfibers Using Ionic Liquid-Based Nanowelding. Biomacromolecules 2011, 12, 4080-4085. [CrossRef]

19. Abbott, A.P.; Capper, G.; Davies, D.L.; Rasheed, R.K.; Tambyrajah, V. Novel solvent properties of choline chloride/urea mixtures. Chem. Commun. 2003, 1, 70-71. [CrossRef]

20. Yousefi, H.; Nishino, T.; Shakeri, A.; Faezipour, M.; Ebrahimi, G.; Kotera, M. Water-repellent all -cellulose nanocomposite using silane coupling treatment. J. Adhes. Sci. Technol. 2013, 27, 1324-1334. [CrossRef]

21. Bian, H.; Tu, P.; Chen, J.Y. Fabrication of all-cellulose nanocomposites from corn stalk. J. Sci. Food Agric. 2020, 100, 4390-4399. [CrossRef]

22. Pandey, J.K.; Nakagaito, A.N.; Takagi, H. Fabrication and applications of cellulose nanoparticle-based polymer composites. Polym. Eng. Sci. 2013, 53, 1-8. [CrossRef]

23. European Union A European Green Deal. 2021. Available online: https:/ / ec.europa.eu/info/strategy/priorities-2019-2024/ european-green-deal_en (accessed on 20 May 2021).

24. European Union Transport Emissions. European Commission Report. 2021. Available online: https://ec.europa.eu/clima/ policies/transport (accessed on 20 May 2021).

25. European Union End-of-Life Vehicles. European Commission Report. 2021. Available online: https://ec.europa.eu/environment/ topics / waste-and-recycling/end-life-vehicles_en (accessed on 20 May 2021).

26. Akampumuza, O.; Wambua, P.M.; Ahmed, A.; Li, W.; Qin, X. Review of the applications of biocomposites in the automotive industry. Polym. Compos. 2017, 38, 2553-2569. [CrossRef]

27. Campilho, R.D.S.G. Recent innovations in biocomposite products. In Biocomposites for High-Performance Applications; Ray, D., Ed.; Woodhead Publishing: Sawston, UK, 2017; pp. 275-306. [CrossRef]

28. Njuguna, J. Lightweight Composite Structures in Transport: Design, Manufacturing, Analysis and Performance; Woodhead Publishing: Sawston, UK, 2016. [CrossRef]

29. Yang, Q.; Saito, T.; Berglund, L.A.; Isogai, A. Cellulose nanofibrils improve the properties of all-cellulose composites by the nano-reinforcement mechanism and nanofibril-induced crystallization. Nanoscale 2015, 7, 17957-17963. [CrossRef]

30. Li, J.; Nawaz, H.; Wu, J.; Zhang, J.; Wan, J.; Mi, Q.; Yu, J.; Zhang, J. All-cellulose composites based on the self-reinforced effect. Compos. Commun. 2018, 9, 42-53. [CrossRef]

31. Budtova T Cellulose II aerogels: A review. Cellulose 2019, 26, 81-121. [CrossRef] 
32. Bos, H.L.; Oever, V.M.J.A.; Peters, O.C.J.J. Tensile and compressive properties of flax fibres for natural fibre reinforced composites. J. Mater. Sci. 2002, 37, 1683-1692. [CrossRef]

33. Sabater, M.J.; Ródenas, T.; Heredia, A. Biopolymers from Plants. In Handbook of Biopolymer-Based Materials: From Blends and Composites to Gels and Complex Networks; Wiley-VCH Verlag GmbH \& Co. KGaA: Weinheim, Germany, 2013; pp. 37-86. [CrossRef]

34. Klemm, D.; Heublein, B.; Fink, H.; Bohn, A. Cellulose: Fascinating Biopolymer and Sustainable Raw Material. Angew. Chem. Int. Ed. 2005, 44, 3358-3393. [CrossRef] [PubMed]

35. Lindman, B.; Karlström, G.; Stigsson, L. On the mechanism of dissolution of cellulose. J. Mol. Liq. 2010, 156, 76-81. [CrossRef]

36. Medronho, B.; Romano, A.; Miguel, M.G.; Stigsson, L.; Lindman, B. Rationalizing cellulose (in)solubility: Reviewing basic physicochemical aspects and role of hydrophobic interactions. Cellulose 2012, 19, 581-587. [CrossRef]

37. Isogai, A.; Hänninen, T.; Fujisawa, S.; Saito, T. Review: Catalytic oxidation of cellulose with nitroxyl radicals under aqueous conditions. Prog. Polym. Sci. 2018, 86, 122-148. [CrossRef]

38. Ciolacu, D.; Ciolacu, F.; Popa, V.I. Amorphous cellulose-structure and characterization. Cellul. Chem. Technol. $2011,45,13-21$.

39. Budtova, T.; Navard, P. Cellulose in NaOH-water based solvents: A review. Cellulose 2016, 23, 5-55. [CrossRef]

40. Winkworth-Smith, C.; Foster, T.J. General overview of biopolymers: Structure, properties, and applications. In Handbook of Biopolymeric Materials; Thomas, S., Durand, D., Chassenieux, C., Jyotishkumar, P., Eds.; Wiley-VCH Verlag GmbH \& Co. KGaA: Weinheim, Germany, 2013.

41. Olsson, C.; Westman, G. Direct Dissolution of Cellulose: Background, Means and Applications. In Cellulose-Fundamental Aspects; Van de Ven, T., Godbout, L., Eds.; IntechOpen: London, UK, 2013. [CrossRef]

42. Kargarzadeh, H.; Ioelovich, M.; Ahmad, I.; Thomas, S.; Dufresne, A. Methods for Extraction of Nanocellulose from Various Sources. In Handbook of Nanocellulose and Cellulose Nanocomposites; Wiley-VCH Verlag GmbH \& Co. KGaA: Weinheim, Germany, 2017; Volume 1, pp. 1-49. [CrossRef]

43. Medronho, B.; Lindman, B. Competing forces during cellulose dissolution: From solvents to mechanisms. Curr. Opin. Colloid Interface Sci. 2014, 19, 32-40. [CrossRef]

44. Cai, C.; Antikainen, J.; Luostarinen, K.; Mononen, K.; Heräjärvi, H. Wetting-induced changes on the surface of thermally modified Scots pine and Norway spruce wood. Wood Sci. Technol. 2018, 52, 1181-1193. [CrossRef]

45. Belgacem, M.N.; Gandini, A. Production, chemistry and properties of cellulose-based materials. In Biopolymers-New Materials for Sustainable Films and Coatings; Plackett, D., Ed.; Wiley: West Sussex, UK, 2011; pp. 151-178. [CrossRef]

46. Dufresne, A. Nanocellulose: From Nature to High Performance Tailored Materials. De Gruyter: Berlin, Germany, 2012. [CrossRef]

47. Ayoub, A.; Lucia, L.A. Introduction to Renewable Biomaterials: First Principles and Concepts; John Wiley \& Sons: Hoboken, NJ, USA, 2018

48. Zugenmaier, P. Crystalline Cellulose and Derivatives: Characterization and Structures, Springer Series in Wood Science; Springer: Berlin, Germany, 2008; pp. 175-206.

49. Kumar, A.; Negi, Y.S. Cellulose Nanocrystals: Nanostrength for Industrial and Biomedical Applications; Wiley-Blackwell: Hoboken, NJ, USA, 2014; pp. 393-435. [CrossRef]

50. Moon, R.J.; Martini, A.; Nairn, J.; Simonsen, J.; Youngblood, J. Cellulose nanomaterials review: Structure, properties and nanocomposites. Chem. Soc. Rev. 2011, 40, 3941-3994. [CrossRef]

51. Turbak, A.F.; Snyder, F.W.; Sandberg, K.R. Microfibrillated cellulose, a new cellulose product: Properties, uses, and commercial potential. Appl. Polym. Sci. 1983, 37, 815-827.

52. Nakagaito, A.N.; Yano, H. Cellulose-Nanofiber-Based Materials. Cellul. Based Compos. New Green Nanomater. $2014,1,1-25$.

53. Hietala, M.; Oksman, K. Technologies for Separation of Cellulose Nanofibers. In Handbook of Green Materials; World Scientific: Singapore, 2014; pp. 53-71.

54. Islam, M.N.; Rahman, F. Production and modification of nanofibrillated cellulose composites and potential applications. In Green Composites for Automotive Applications; Koronis, G., Silva, A., Eds.; Woodhead Publishing: Sawston, UK, 2019 ; pp. 115-141.

55. Saito, T.; Isogai, A. TEMPO-Mediated Oxidation of Native Cellulose. The Effect of Oxidation Conditions on Chemical and Crystal Structures of the Water-Insoluble Fractions. Biomacromolecules 2004, 5, 1983-1989. [CrossRef] [PubMed]

56. Filipova, I.; Serra, F.; Tarrés, Q.; Mutjé, P.; Delgado-Aguilar, M. Oxidative treatments for cellulose nanofibers production: A comparative study between TEMPO-mediated and ammonium persulfate oxidation. Cellulose 2020, 27, 10671-10688. [CrossRef]

57. Wågberg LDecher GNorgren, M.; Lindström, T.; Ankerfors, M.; Axnäs, K. The Build-Up of Polyelectrolyte Multilayers of Microfibrillated Cellulose and Cationic Polyelectrolytes. Langmuir 2008, 24, 784-795. [CrossRef]

58. Sirviö, J.A. Cationization of lignocellulosic fibers with betaine in deep eutectic solvent: Facile route to charge stabilized cellulose and wood nanofibers. Carbohydr. Polym. 2018, 198, 34-40. [CrossRef] [PubMed]

59. de Souza Lima, M.M.; Borsali, R. Rodlike Cellulose Microcrystals: Structure, Properties, and Applications. Macromol. Rapid Commun. 2004, 25, 771-787. [CrossRef]

60. Eichhorn, S.J. Characterization of Cellulose Nanofiber-based Nanocomposite Interfaces. In Handbook of Green Materials; World Scientific: Hackensack, NJ, USA, 2014; pp. 107-120. [CrossRef]

61. Zadorecki, P.; Michell, A.J. Future prospects for wood cellulose as reinforcement in organic polymer composites. Polym. Compos. 1989, 10, 69-77. [CrossRef]

62. Oksman Niska, K.; Mathew, A.P.; Bismarck, A.; Rojas, O.J.; Sain, M. Handbook of Green Materials: Processing Technologies, Properties and Applications; World Scientific: Hackensack, NJ, USA, 2014. 
63. Huang, S.; Liu, X.; Chang, C.; Wang, Y. Recent developments and prospective food-related applications of cellulose nanocrystals: A review. Cellulose 2020, 27, 2991-3011. [CrossRef]

64. Hult, E.; Larsson, P.T.; Iversen, T. Cellulose fibril aggregation-An inherent property of kraft pulps. Polymer 2001, 42, 3309-3314. [CrossRef]

65. Eyholzer, C.; Bordeanu, N.; Lopez-Suevos, F.; Rentsch, D.; Zimmermann, T.; Oksman, K. Preparation and characterization of water-redispersible nanofibrillated cellulose in powder form. Cellulose 2009, 17, 19-30. [CrossRef]

66. Kalia, S.; Dufresne, A.; Cherian, B.M.; Kaith, B.S.; Avérous, L.; Njuguna, J.; Nassiopoulos, E. Cellulose-Based Bio- and Nanocomposites: A Review. Int. J. Polym. Sci. 2011, 2011, 1-35. [CrossRef]

67. Wang, Y.; Zhao, Y.; Deng, Y. Effect of enzymatic treatment on cotton fiber dissolution in $\mathrm{NaOH} /$ urea solution at cold temperature. Carbohydr. Polym. 2008, 72, 178-184. [CrossRef]

68. Medronho, B.; Lindman, B. Brief overview on cellulose dissolution/regeneration interactions and mechanisms. Adv. Colloid Interface Sci. 2015, 222, 502-508. [CrossRef]

69. Liebert, T. Cellulose Solvents-Remarkable History, Bright Future. In Cellulose Solvents: For Analysis, Shaping and Chemical Modification; American Chemical Society: Washington, DC, USA, 2010; pp. 3-54.

70. Klemm, D.; Philipp, B.; Heinze, T.; Heinze, U.; Wagenknecht, W. Comprehensive Cellulose Chemistry. In Fundamentals and Analytical Methods; Wiley-VCH Verlag GmbH \& Co. KGaA: Weinheim, Germany, 1998; Volume 1, p. 260. [CrossRef]

71. Holme, I.; Blackburn, R.S. John Mercer FRS, FCS, MPhS, JP: The Father of Textile Chemistry. Coloration Technol. 2019, 135, 171-182. [CrossRef]

72. Nabinejad, O.; Sujan, D.; Rahman, M.; Davies, I.J. Effect of filler load on the curing behavior and mechanical and thermal performance of wood flour filled thermoset composites. J. Clean. Prod. 2017, 164, 1145-1156. [CrossRef]

73. Wada, M.; Ike, M.; Tokuyasu, K. Enzymatic hydrolysis of cellulose I is greatly accelerated via its conversion to the cellulose II hydrate form. Polym. Degrad. Stab. 2010, 95, 543-548. [CrossRef]

74. Sameii, N.; Mortazavi, S.; Rashidi, A.; Sheikhzadah-Najar, S. An investigation on the effect of hot mercerization on cotton fabrics made up of open-end yarns. J. Appl. Sci. 2008, 8, 4204-4209. [CrossRef]

75. Okano, T.; Sarko, A. Mercerization of cellulose. II. Alkali-cellulose intermediates and a possible mercerization mechanism. J. Appl. Polym. Sci. 1985, 30, 325-332. [CrossRef]

76. Fink, H.; Ganster, J.; Lehmann, A. Progress in cellulose shaping: 20 years industrial case studies at Fraunhofer IAP. Cellulose 2014, 21, 31-51. [CrossRef]

77. Jiang, Z.; Fang, Y.; Xiang, J.; Ma, Y.; Lu, A.; Kang, H.; Huang, Y.; Guo, H.; Liu, R.; Zhang, L. Intermolecular Interactions and 3D Structure in Cellulose-NaOH-Urea Aqueous System. J. Phys. Chem. B 2014, 118, 10250-10257. [CrossRef] [PubMed]

78. Määttänen, M.; Gunnarsson, M.; Wedin, H.; Stibing, S.; Olsson, C.; Köhnke, T.; Asikainen, S.; Vehviläinen, M.; Harlin, A. Pre-treatments of pre-consumer cotton-based textile waste for production of textile fibres in the cold $\mathrm{NaOH}(\mathrm{aq})$ and cellulose carbamate processes. Cellulose 2021, 28, 3869-3886. [CrossRef]

79. Heinze, T.; Koschella, A. Solvents applied in the field of cellulose chemistry: A mini review. Polimeros Ciência Tecnol. 2005, 15, 84-90. [CrossRef]

80. Wang, S.; Lu, A.; Zhang, L. Recent advances in regenerated cellulose materials. Prog. Polym. Sci. 2016, 53, 169-206. [CrossRef]

81. Chen, Y.; Zhang, X.; You, T.; Xu, F. Deep eutectic solvents (DESs) for cellulose dissolution: A mini-review. Cellulose 2019, 26, 205-213. [CrossRef]

82. Weißl, M.; Hobisch, M.A.; Johansson, L.S.; Hettrich, K.; Kontturi, E.; Volkert, B.; Spirk, S. Cellulose carbamate derived cellulose thin films: Preparation, characterization and blending with cellulose xanthate. Cellulose 2019, 26, 7399-7410. [CrossRef]

83. Guo, Y.; Zhou, J.; Song, Y.; Zhang, L. An Efficient and Environmentally Friendly Method for the Synthesis of Cellulose Carbamate by Microwave Heating. Macromol. Rapid Commun. 2009, 30, 1504-1508. [CrossRef]

84. Xiong, L.; Yu, G.; Yin, C. Synthesis and characterization of cellulose carbamate by liquid-solid phase method. Fibers Polym. 2017, 18, 88-94. [CrossRef]

85. Paunonen, S.; Kamppuri, T.; Katajainen, L.; Hohenthal, C.; Heikkilä, P.; Harlin, A. Environmental impact of cellulose carbamate fibers from chemically recycled cotton. J. Clean. Prod. 2019, 222, 871-881. [CrossRef]

86. Sainila, T. Stability and Properties of Cellulose-Sodium Hydroxide Solution Systems; Lappeenranta University of Technology: Lappeenranta, Finland, 2015.

87. Fu, F.; Xu, M.; Wang, H.; Wang, Y.; Ge, H.; Zhou, J. Improved Synthesis of Cellulose Carbamates with Minimum Urea Based on an Easy Scale-up Method. ACS Sustain. Chem. Eng. 2015, 3, 1510-1517. [CrossRef]

88. Harlin, A. Cellulose Carbamate: Production and Applications; VTT Technical Research Centre of Finland: Espoo, Finland, 2019.

89. Yin, C.; Li, J.; Xu, Q.; Peng, Q.; Liu, Y.; Shen, X. Chemical modification of cotton cellulose in supercritical carbon dioxide: Synthesis and characterization of cellulose carbamate. Carbohydr. Polym. 2007, 67, 147-154. [CrossRef]

90. Zhang, Y.; Yin, C.; Zhang, Y.; Wu, H. Synthesis and Characterization of Cellulose Carbamate from Wood Pulp, Assisted by Supercritical Carbon Dioxide. BioResources 2013, 8, 1398-1408. [CrossRef]

91. Fu, F.; Zhou, J.; Zhou, X.; Zhang, L.; Li, D.; Kondo, T. Green Method for Production of Cellulose Multifilament from Cellulose Carbamate on a Pilot Scale. ACS Sustain. Chem. Eng. 2014, 2, 2363-2370. [CrossRef]

92. Iller, E.; Stupińska, H.; Starostka, P. Properties of cellulose derivatives produced from radiation-Modified cellulose pulps. Radiat. Phys. Chem. (Oxf. Engl. 1993) 2007, 76, 1189-1194. [CrossRef] 
93. Huttunen, J.I.; Turunen, O.; Mandel, L.; Eklund, V.; Ekman, K. Method of Producing Alkali-Soluble Cellulose Derivative. CAN97:146443. EP 57105A2, 4 August 1982.

94. Willberg-Keyriläinen, P.; Hiltunen, J.; Roppanen, J. Production of cellulose carbamate using urea-based deep eutectic solvents. Cellulose 2018, 25, 195-204. [CrossRef]

95. Sharma, A.; Nagarkar, S.; Thakre, S.; Kumaraswamy, G. Structure-property relations in regenerated cellulose fibers: Comparison of fibers manufactured using viscose and lyocell processes. Cellulose 2019, 26, 3655-3669. [CrossRef]

96. Das, M. Man-made cellulose fibre reinforcements (MMCFR). In Biocomposites for High-Performance Applications; Ray, D., Ed.; Woodhead Publishing: Sawston, UK, 2017; pp. 23-55.

97. Wendler, F.; Kolbe, A.; Kraft, J.; Einax, J.W.; Heinze, T. Thermal Stability of Lyocell Solutions: Experimental Results and Modeling Using Cluster Analysis and Partial Least Squares Regression. Macromol. Theory Simul. 2008, 17, 32-38. [CrossRef]

98. Chen, C.; Duan, C.; Li, J.; Liu, Y.; Ma, X.; Zheng, L.; Stavik, J.; Ni, Y. Cellulose (Dissolving Pulp) Manufacturing Processes and Properties: A Mini-Review. BioResources 2016, 11, 5553-5564. [CrossRef]

99. McCormick, C.L.; Callais, P.A.; Hutchinson, B.H. Solution studies of cellulose in lithium-chloride and N,N-dimethylacetamide. Macromolecules 1985, 18, 2394-2401. [CrossRef]

100. Chrapava, S.; Touraud, D.; Rosenau, T.; Potthast, A.; Kunz, W. The investigation of the influence of water and temperature on the $\mathrm{LiCl} / \mathrm{DMAc} /$ cellulose system. Chem. Phys. 2003, 5, 1842-1847. [CrossRef]

101. Soykeabkaew, N.; Nishino, T.; Peijs, T. All-cellulose composites of regenerated cellulose fibres by surface selective dissolution Compos. Part A Appl. Sci. Manuf. 2009, 40, 321-328. [CrossRef]

102. Fujisawa, S.; Saito, T.; Isogai, A. All-Cellulose (Cellulose-Cellulose) Green Composites. In Advanced Green Composites; Netravali, A., Ed.; John Wiley \& Sons: Hoboken, NJ, USA, 2018; pp. 111-133. [CrossRef]

103. Matsumoto, T.; Tatsumi, D.; Tamai, N.; Takaki, T. Solution properties of celluloses from different biological origins in LiCl-DMAc. Cellulose 2001, 8, 275-282. [CrossRef]

104. Alexandridis, P.; Ghasemi, M.; Furlani, E.P.; Tsianou, M. Solvent processing of cellulose for effective bioresource utilization. Curr. Opin. Green Sustain. Chem. 2018, 14, 40-52. [CrossRef]

105. Pinkert, A.; Marsh, K.; Pang, S.; Staiger, M. Ionic liquids and their interaction with cellulose. Chem. Rev. 2009, 109, 6712-6728. [CrossRef] [PubMed]

106. Bowlas, C.J.; Bruce, D.W.; Seddon, K.R. Liquid-crystalline ionic liquids. Chem. Commun. 1996, 14, 1625-1626. [CrossRef]

107. Michud, A.; Hummel, M.; Sixta, H. Influence of process parameters on the structure formation of man-made cellulosic fibers from ionic liquid solution. J. Appl. Polym. Sci. 2016, 133, 43718. [CrossRef]

108. Zhu, S.; Wu, Y.; Chen, Q.; Yu, Z.; Wang, C.; Jin, S.; Ding, Y.; Wu, G. Dissolution of cellulose with ionic liquids and its application: A mini-review. Green Chem. 2006, 8, 325-327. [CrossRef]

109. Zhao, Q.; Yam, R.C.M.; Zhang, B.; Yang, Y.; Cheng, X.; Li, R.K.Y. Novel all-cellulose ecocomposites prepared in ionic liquids. Cellulose 2009, 16, 217-226. [CrossRef]

110. Ma, Y.; Nasri-Nasrabadi, B.; You, X.; Wang, X.; Rainey, T.J.; Byrne, N. Regenerated Cellulose Fibers Wetspun from Different Waste Cellulose Types. J. Nat. Fibers 2020, 1-13. [CrossRef]

111. Ioncell Commercialization. 2021. Available online: https://ioncell.fi/commercialization (accessed on 26 May 2021).

112. Roselli, A.; Hummel, M.; Monshizadeh, A.; Maloney, T.; Sixta, H. Ionic liquid extraction method for upgrading eucalyptus kraft pulp to high purity dissolving pulp. Cellulose 2014, 21, 3655-3666. [CrossRef]

113. Elsayed, S.; Hellsten, S.; Guizani, C.; Witos, J.; Rissanen, M.; Rantamäki, A.H.; Varis, P.; Wiedmer, S.K.; Sixta, H. Recycling of Superbase-Based Ionic Liquid Solvents for the Production of Textile-Grade Regenerated Cellulose Fibers in the Lyocell Process. ACS Sustain. Chem. Eng. 2020, 8, 14217-14227. [CrossRef]

114. Dai, Y.; van Spronsen, J.; Witkamp, G.; Verpoorte, R.; Choi, Y.H. Natural deep eutectic solvents as new potential media for green technology. Anal. Chim. Acta. 2013, 766, 61-68. [CrossRef]

115. Zhang, Q.; De Oliveira Vigier, K.; Royer, S.; Jérôme, F. Deep eutectic solvents: Syntheses, properties and applications. Chem. Soc. Rev. 2012, 41, 718-7146. [CrossRef]

116. Tenhunen, T.; Lewandowska, A.E.; Orelma, H.; Johansson, L.; Virtanen, T.; Harlin, A.; Österberg, M.; Eichhorn, S.J.; Tammelin, $\mathrm{T}$. Understanding the interactions of cellulose fibres and deep eutectic solvent of choline chloride and urea. Cellulose 2018, 25, 137-150. [CrossRef]

117. Davidson, G. The dissolution of chemically modified cotton cellulose in alkaline solutions. Part 3-In solutions of sodium and potassium hydroxide containing dissolved zinc, beryllium and aluminium oxides. J. Text. Inst. Trans. 1937, 28, T27-T44. [CrossRef]

118. Cai, J.; Zhang, L. Rapid Dissolution of Cellulose in LiOH/Urea and NaOH/Urea Aqueous Solutions. Macromol. Biosci. 2005, 5, 539-548. [CrossRef] [PubMed]

119. Xiong, B.; Zhao, P.; Cai, P.; Zhang, L.; Hu, K.; Cheng, G. NMR spectroscopic studies on the mechanism of cellulose dissolution in alkali solutions. Cellulose 2013, 20,613-621. [CrossRef]

120. Gan, S.; Mohammad Padzil, F.N.; Zakaria, S.; Chia, C.H.; Syed Jaafar, S.N.; Chen, R.S. Synthesis of Liquid Hot Water Cotton Linter to Prepare Cellulose Membrane using NaOH/Urea or LiOH/Urea. BioResources 2015, 10, 2244-2255. [CrossRef] 
121. Qiu, C.; Zhu, K.; Zhou, X.; Luo, L.; Zeng, J.; Huang, R.; Lu, A.; Liu, X.; Chen, F.; Zhang, L.; et al. Influences of Coagulation Conditions on the Structure and Properties of Regenerated Cellulose Filaments via Wet-Spinning in LiOH/Urea Solvent. ACS Sustain. Chem. Eng. 2018, 6, 4056-4067. [CrossRef]

122. Zhang, L.; Ruan, D.; Zhou, J. Structure and Properties of Regenerated Cellulose Films Prepared from Cotton Linters in NaOH/Urea Aqueous Solution. Ind. Eng. Chem. Res. 2001, 40, 5923-5928. [CrossRef]

123. Cai, J.; Zhang, L.; Zhou, J.; Li, H.; Chen, H.; Jin, H. Novel Fibers Prepared from Cellulose in NaOH/Urea Aqueous Solution. Macromol. Rapid Commun. 2004, 25, 1558-1562. [CrossRef]

124. Lu, F.; Zhang, C.; Kang, H.; Huang, Y.; Liu, R. Extensional rheology of cellulose/ $\mathrm{NaOH} / \mathrm{urea} / \mathrm{H}_{2} \mathrm{O}$ solutions. Cellulose 2016, 23, 2877-2885. [CrossRef]

125. Ruan, D.; Zhang, L.; Lue, A.; Zhou, J.; Chen, H.; Chen, X.; Chu, B.; Kondo, T. A Rapid Process for Producing Cellulose Multi-Filament Fibers from a NaOH/Thiourea Solvent System. Macromol. Rapid Commun. 2006, 27, 1495-1500. [CrossRef]

126. Zhang, L.; Ruan, D.; Gao, S. Dissolution and regeneration of cellulose in $\mathrm{NaOH} /$ thiourea aqueous solution. Journal of polymer science. Part B Polym. Phys. 2002, 40, 1521-1529. [CrossRef]

127. Zhang, Q.; Wang, Z.; Hao, S.; Huang, J. Preparation of all-cellulose composites based on controlled dissolution procedure. Starch/Staerke 2021. [CrossRef]

128. Liu, W.; Budtova, T.; Navard, P. Influence of $\mathrm{ZnO}$ on the properties of dilute and semi-dilute cellulose-NaOH-water solutions. Cellulose 2011, 18, 911-920. [CrossRef]

129. Väisänen, T.; Batello, P.; Lappalainen, R.; Tomppo, L. Modification of hemp fibers (Cannabis Sativa L.) for composite applications. Ind. Crop. Prod. 2018, 111, 422-429. [CrossRef]

130. Yan, L.; Gao, Z. Dissolving of cellulose in PEG/NaOH aqueous solution. Cellulose 2008, 15, 789-796. [CrossRef]

131. Han, D.; Yan, L. Preparation of all-cellulose composite by selective dissolving of cellulose surface in PEG/NaOH aqueous solution. Carbohydr. Polym. 2010, 79, 614-619. [CrossRef]

132. Xiong, B.; Zhao, P.; Hu, K.; Zhang, L.; Cheng, G. Dissolution of cellulose in aqueous NaOH/urea solution: Role of urea. Cellulose 2014, 21, 1183-1192. [CrossRef]

133. Qi, H.; Chang, C.; Zhang, L. Effects of temperature and molecular weight on dissolution of cellulose in $\mathrm{NaOH} /$ urea aqueous solution. Cellulose 2008, 15, 779-787. [CrossRef]

134. Li, R.; Wang, S.; Lu, A.; Zhang, L. Dissolution of cellulose from different sources in an $\mathrm{NaOH} /$ urea aqueous system at low temperature. Cellulose 2015, 22, 339-349. [CrossRef]

135. Sun, H.; Miao, J.; Yu, Y.; Zhang, L. Dissolution of cellulose with a novel solvent and formation of regenerated cellulose fiber. Appl. Phys. A 2015, 119, 539-546. [CrossRef]

136. Mokhothu, T.H.; John, M.J. Review on hygroscopic aging of cellulose fibres and their biocomposites. Carbohydr. Polym. 2015, 131, 337-354. [CrossRef] [PubMed]

137. Takagi, H. Fabrication and Evaluation of Cellulose-Nanofiber-Reinforced Green Composites. In Cellulose Based Composites: New Green Nanomaterials; Hinestroza, J.P., Netravali, A.N., Eds.; Wiley-VCH Verlag GmbH \& Co. KGaA: Weinheim, Germany, 2014; pp. 27-42. [CrossRef]

138. Célino, A.; Fréour, S.; Jacquemin, F.; Casari, P. The hygroscopic behavior of plant fibers: A review. Front. Chem. $2014,1,43$. [CrossRef]

139. Björquist, S.; Aronsson, J.; Henriksson, G.; Persson, A. Textile qualities of regenerated cellulose fibers from cotton waste pulp. Text. Res. J. 2018, 88, 2485-2492. [CrossRef]

140. Renewcell Technology. 2021. Available online: https://www.renewcell.com/en/section/our-technology (accessed on 20 May 2021).

141. Ganster, J.; Fink, H.; Uihlein, K.; Zimmerer, B. Cellulose man-made fibre reinforced polypropylene-correlations between fibre and composite properties. Cellulose 2008, 15, 561-569. [CrossRef]

142. Tan, P.; Tong, L.; Steven, G.P. Modelling for predicting the mechanical properties of textile composites-A review. Compos. Part A Appl. Sci. Manuf. 1997, 28, 903-922. [CrossRef]

143. Jones, I.A.; Pickett, A.K. Mechanical properties of textile composites. In Design and Manufacture of Textile Composites; Long, A.C., Ed.; Woodhead Publishing: Sawston, UK, 2005; pp. 292-329. [CrossRef]

144. Kabir, S.M.F.; Chakraborty, S.; Hoque, S.M.A.; Mathur, K. Sustainability Assessment of Cotton-Based Textile Wet Processing. Clean Technol. 2019, 1, 16. [CrossRef]

145. Mathur, K. New Developments in Fibers, Yarns \& Fabrics. Text. World 2020, 170, 32-35.

146. Ecovero; The New Standard in Eco-Responsible. 2021. Available online: https:/ / www.ecovero.com (accessed on 20 May 2021).

147. Lenzing; Tencel, T.M. 2021. Available online: https://www.lenzing.com/products/tenceltm. (accessed on 20 May 2021).

148. Kuura; Metsä Group's New Textile Fibre is Kuura. 2021. Available online: https:/ /www.kuura.io/metsa-groups-new-textilefibre-is-kuura (accessed on 1 June 2021).

149. Infinited Fiber. It's Time for the Textile Industry to Lose Its Virginity. 2021. Available online: https://infinitedfiber.com (accessed on 20 May 2021).

150. Haksa Textile Environmentally Friendly Yarn. 2021. Available online: http://haksatekstil.com.tr/en/home-page (accessed on 20 May 2021).

151. Spinnova Technology. 2021. Available online: https:/ / spinnova.com/technology (accessed on 20 May 2021). 
152. Temmink, R.; Baghaei, B.; Skrifvars, M. Development of biocomposites from denim waste and thermoset bio-resins for structural applications. Compos. Part A Appl. Sci. Manuf. 2018, 106, 59-69. [CrossRef]

153. Baghaei, B.; Compiet, S.; Skrifvars, M. Mechanical properties of all-cellulose composites from end-of-life textiles. J. Polym. Res. 2020, 27, 1-9. [CrossRef]

154. Chinga-Carrasco, G. (Ed.) Novel Biocomposite Engineering and Bio-Applications; MDP-Multidisciplinary Digital Publishing institute: Basel, Switzerland, 2019. [CrossRef]

155. Müssig, J.; Stevens, C. Industrial Applications of Natural Fibres: Structure, Properties and Technical Applications; Wiley-VCH Verlag $\mathrm{GmbH} \& \mathrm{Co}$ : Weinheim, Germany, 2010. [CrossRef]

156. Kumar, T.V.; Singh, S.A. Natural Plant Fibre Biocomposites for Structural Vehicle Components. In Biomass-Based Biocomposites; Smithers Rapra Technology: Shawbury, UK, 2013.

157. Mohanty, A.K.; Misra, M.; Drzal, L.T. Sustainable Bio-Composites from Renewable Resources: Opportunities and Challenges in the Green Materials World. J. Polym. Environ. 2002, 10, 19-26. [CrossRef]

158. Väisänen, S.; Ajdary, R.; Altgen, M.; Nieminen, K.; Kesari, K.K.; Ruokolainen, J.; Rojas, O.J.; Vuorinen, T. Cellulose dissolution in aqueous $\mathrm{NaOH}-\mathrm{ZnO}$ : Cellulose reactivity and the role of ZnO. Cellulose 2021, 28, 1267-1281. [CrossRef]

159. John, M.J.; Thomas, S. Biofibres and biocomposites. Carbohydr. Polym. 2008, 71, 343-364. [CrossRef]

160. Sorieul, M.; Dickson, A.; Hill, S.; Pearson, H. Plant Fibre: Molecular Structure and Biomechanical Properties, of a Complex Living Material, Influencing Its Deconstruction towards a Biobased Composite. Materials 2016, 9, 618. [CrossRef]

161. Lee, K.Y.; Bismarck, A. Green Chemical Modifications of Nanocellulose for Use in Composites. Handb. Green Mater. $2014,2,7-21$.

162. Campbell, F.C. Structural Composite Materials; ASM International: Almere, The Netherlands, 2010.

163. Thakur, V.K.; Thakur, M.K.; Kessler, M.R. Handbook of Composites from Renewable Materials. Physico-Chemical and Mechanical Characterization; Scrivener Publishing: Austin, TX, USA, 2017; Volume 3.

164. Baghaei, B.; Skrifvars, M. All-Cellulose Composites: A Review of Recent Studies on Structure, Properties and Applications. Molecule 2020, 25, 2836. [CrossRef]

165. Alcock, B.; Cabrera, N.O.; Barkoula, N.-; Loos, J.; Peijs, T. The mechanical properties of unidirectional all-polypropylene composites. Compos. Part A Appl. Sci. Manuf. 2006, 37, 716-726. [CrossRef]

166. Retegi Miner, A.; Zuluaga Gallego, R.; Gañán Rojo, P.; Mondragon, I. Nanocomposites Based on Matrices Extracted from Vegetable Oils and Bacterial Cellulose. In Cellulose Based Composites: New Green Nanomaterials; Hinestroza, J.P., Netravali, A.N., Eds.; John Wiley \& Sons: Hoboken, NJ, USA, 2014; pp. 63-78. [CrossRef]

167. Capiati, N.J.; Porter, R.S. The concept of one polymer composites modelled with high density polyethylene. J. Mater. Sci. 1975, 10, 1671-1677. [CrossRef]

168. Phillips, H.M. Vulcanized Fibre. U.S. Patent 3,189,515, 15 June 1965.

169. Brown, W.F. Vulcanized fibre-an old material with a new relevancy. In Proceedings of the Electrical Insulation Conference and Electrical Manufacturing and Coil Winding Conference, Cincinnati, OH, USA, 28 October 1999; pp. 309-312.

170. Huber, T.; Bickerton, S.; Müssig, J.; Pang, S.; Staiger, M.P. Flexural and impact properties of all-cellulose composite laminates. Compos. Sci. Technol. 2013, 88, 92-98. [CrossRef]

171. Piltonen, P.; Hildebrandt, N.C.; Westerlind, B.; Valkama, J.; Tervahartiala, T.; Illikainen, M. Green and efficient method for preparing all-cellulose composites with $\mathrm{NaOH} /$ urea solvent. Compos. Sci. Technol. 2016, 135, 153-158. [CrossRef]

172. Hildebrandt, N.C.; Piltonen, P.; Valkama, J.; Illikainen, M. Self-reinforcing composites from commercial chemical pulps via partial dissolution with $\mathrm{NaOH} /$ urea. Ind. Crop. Prod. 2017, 109, 79-84. [CrossRef]

173. Korhonen, O.; Sawada, D.; Budtova, T. All-cellulose composites via short-fiber dispersion approach using NaOH-water solvent. Cellulose 2019, 26, 4881-4893. [CrossRef]

174. Pickering, K.; Efendy, M.G.A.; Le, T. A review of recent developments in natural fibre composites and their mechanical performance. Compos. Part A Appl. Sci. Manuf. 2016, 83, 98-112. [CrossRef]

175. Adusumali, R.; Reifferscheid, M.; Weber, H.; Roeder, T.; Sixta, H.; Gindl, W. Mechanical Properties of Regenerated Cellulose Fibres for Composites. Macromol. Symp. 2006, 244, 119-125. [CrossRef]

176. Kalka, S.; Huber, T.; Steinberg, J.; Baronian, K.; Müssig, J.; Staiger, M.P. Biodegradability of all-cellulose composite laminates. Compos. Part A Appl. Sci. Manuf. 2014, 59, 37-44. [CrossRef]

177. Lee, K.Y.; Aitomäki, Y.; Berglund, L.A.; Oksman, K.; Bismarck, A. On the use of nanocellulose as reinforcement in polymer matrix composites. Compos. Sci. Technol. 2014, 105, 15-27. [CrossRef]

178. Yousefi, H.; Faezipour, M.; Nishino, T.; Shakeri, A.; Ebrahimi, G. All-cellulose composite and nanocomposite made from partially dissolved micro-and nanofibers of canola straw. Polym. J. 2011, 43, 559-564. [CrossRef]

179. Pullawan, T.; Wilkinson, A.N.; Zhang, L.N.; Eichhorn, S.J. Deformation micromechanics of all-cellulose nanocomposites: Comparing matrix and reinforcing components. Carbohydr. Polym. 2014, 100, 31-39. [CrossRef]

180. Peltola, H.P.; Madsen, B.; Joffe, R.; Nättinen, K. The Influence of Biocomposite Processing and Composition on Natural Fiber Length, Dispersion and Orientation. J. Mater. Sci. Eng. A 2011, 1, 190-198.

181. Duchemin, B.J. Structure, Property and Processing Relationships of All-Cellulose Composites; University of Canterbury: Christchurch, New Zealand, 2008.

182. Adak, B.; Mukhopadhyay, S. Effect of pressure on structure and properties of lyocell fabric-based all-cellulose composite laminates. J. Text. Inst. 2017, 108, 1010-1017. [CrossRef] 
183. Qin, C.; Soykeabkaew, N.; Xiuyuan, N.; Peijs, T. The effect of fibre volume fraction and mercerization on the properties of all-cellulose composites. Carbohydr. Polym. 2008, 71, 458-467. [CrossRef]

184. Li, D.; Sun, X.; Khaleel, M.A. Materials design of all-cellulose composite using microstructure based finite element analysis. J. Eng. Mater. Technol. 2012, 134, 1-9. [CrossRef]

185. Adak, B.; Mukhopadhyay, S. A comparative study on lyocell-fabric based all-cellulose composite laminates produced by different processes. Cellulose 2017, 24, 835-849. [CrossRef]

186. Charlet, K.; Baley, C.; Morvan, C.; Jernot, J.; Gomina, M.; Bréard, J. Characteristics of Hermès flax fibres as a function of their location in the stem and properties of the derived unidirectional composites. Compos. Part A Appl. Sci. Manuf. 2007, 38, $1912-1921$. [CrossRef]

187. Buchtová, N.; Budtova, T. Cellulose aero-, cryo- and xerogels: Towards understanding of morphology control. Cellulose 2016, 23, 2585-2595. [CrossRef]

188. Shibata, M.; Teramoto, N.; Nakamura, T.; Saitoh, Y. All-cellulose and all-wood composites by partial dissolution of cotton fabric and wood in ionic liquid. Carbohydr. Polym. 2013, 98, 1532-1539. [CrossRef] [PubMed]

189. Schuermann, J.; Huber, T.; Staiger, M. Prepreg style fabrication of all-cellulose composites. ICCM Int. Conf. Compos. Mater. 2013, 2013, 5626-5634. 